\title{
КОМПЛЕКСНИЙ ПІДХІД ДО АНАЛІЗУ ОСВІТНЬО-НАУКОВИХ ПРОГРАМ СПЕЦІАЛЬНОСТІ «ФАРМАЦІЯ, ПРОМИСЛОВА ФАРМАЦІЯ» У РОЗРІЗІ СВРОІНТЕГРАЦІЇ
}

\author{
Кричковська А. М., Заярнюк Н. Л., Конечна Р. Т.
}

\section{ВСТУП}

У всьому світі приділяється особлива увага забезпеченню якості вищої освіти. В Україні, яка взяла сталий політичний курс наЄвроінтеграцію з країнами СС, також відбуваються значні зміни у забезпеченні якості вищої освіти $[1, \text { с. 68] }]^{1}$ У 2019 році в Україні створено Національне агентство з забезпечення якості вищої освіти (НАЗЯВО), яке проводить процедуру акредитації закладів вищої освіти (3ВО) $[2, \text { с. } 5]^{2} ;[3, \text { с. } 1]^{3}$. Незалежний освітній аудит відбувається за участі НАЗЯО за спеціальностями та рівнями освіти в ЗВО $[4, \text { с. } 4]^{4}$.

Саме 3 метою проведення порівняльної характеристики підготовки студентів другого та третього освітньо-наукових рівнів спеціальності 226 «Фармація, промислова фармація» нами була зібрана інформація про аналогічні освітньо-наукові програми (ОНП) в Україні та за кордоном.

Існувало дві передумови для створення нових ОНП загалом у всіх ЗВО в Україні, а також у Національному університеті «Львівська політехніка» (НУЛП). Згідно 3 постановою Кабінету Міністрів

1 Мельничук О.Ф. Правові засади діяльності Національного агентства із забезпечення якості вищої освіти в умовах євроінтеграції. Публічне право: науковопрактичний юридичний журнал. 2017. № 1 (25). С. 67-72.

${ }^{2}$ Солоденко А.К., Погребняк В.П., Дашковська О.В. Національне агентство із забезпечення якості вищої освіти - довгий шлях створення. Вісник Національного технічного університету «ХПІ» : зб. наук. пр. Харків : НТУ «ХПІ». 2019. № 9 (1334). C. 4-8. (doi: 10.20998/2079-8024.2019.9.01).

${ }^{3}$ Про утворення Національного агентства із забезпечення якості вищої освіти. Постанова КМУ № 244 від15.04.2015, поточна редакція від 28.08.2019. URL: https://zakon.rada.gov.ua/laws/show/244-2015-п.

${ }^{4}$ Серняк O.I. Незалежний освітній аудитор як суб'єкт громадського механізму забезпечення якості вищої освіти. Демократичне врядування: наук. вісн. Вип. 1(23) / за ред. чл.-кор. НАН України В.С. Загорського, доц. А.В. Ліпенцева. Львів: ЛРІДУ НАДУ, 2019. URL: www.dv.lvivacademy.com (doi:https://doi.org/10.33990/20704038.23.2019.181484). 
України від 29 квітня 2015 року № 266 «Про затвердження переліку галузей знань і спеціальностей, за якими здійснюється підготовка здобувачів вищої освіти» (зі змінами), наказом МОН України від 06.11.2015 р. № 1151 «Про особливості запровадження переліку галузей i спеціальностей, за якими здійснюється підготовка здобувачів вищої освіти» спеціальність 15.00.01 «Технологія ліків, організація фармацевтичної справи та судова фармація» була уніфікована та започаткована як спеціальність 226 «Фармація, промислова фармація» (галузь знань 22 Охорона здоров'я).

Нова спеціальність вважалась спорідненою до спеціальності 15.00.01 «Технологія ліків, організація фармацевтичної справи та судова фармація», за якою на кафедрі Технології біологічно активних сполук, фармації та біотехнології (ТБСФБ) НУЛП вже здійснювалась підготовка здобувачів третього (освітньо-наукового) рівня вищої освіти та іiі ліцензування було здійснено у 2016 році. Вступ на спеціальність 226 «Фармація, промислова фармація» на третій (освітньо-науковий) рівень вищої освіти здійснюється на основі диплому про вищу освіту хімічних та фармацевтичних спеціальностей і результатів вступних іспитів.

НУЛП в період 2016-2020 років виступав партнером діючого договору про подвійні дипломи з Університетом Ле-Ман (м. Дю Мен, Франція), в рамках підписаних угод про міжнародну академічну мобільність в рамках програми Erasmus+KA1 3 Університетом Ле-Ман (м. Дю Мен, Франція), Опольським університетом (м. Ополе, Польща), Університетом Тулузи III Пауль Сабатьє (м Тулуза, Франція), ISA LILLE (м. Лілль, Франція) були здійснені поїздки студентів для навчання на магістерських програмах, аспірантів для проведення досліджень та викладачів для читання лекцій та проходження тренінгів. Крім того, НУЛП в період 2016-2020 років виступав партнером проєктів між народного двостороннього науково-технічного співробітництва: УкраїнаФранція М/85-2017, М/113-2018 «Створення сульфуровмісних похідних карбоциклічних та гетероциклічних систем - потенційних антитромботичних субстанцій» (2017-2018рр.); Україна-Польща M/120-2018, М/42-2019 «Похідні 9,10-антрахінону та споріднених карбо- i гетероциклічних систем як прототипи потенційних протипухлинних та протигрибкових субстанцій» (2018-2019рр.). У рамках угоди про співпрацю між Опольським університетом (м. Ополе, Польща) та НУЛП відбулися стажування викладачів. 
Отже, робочою групою науково-методичної комісії спеціальності 226 «Фармація, промислова фармація» НУЛП було розроблено ОНП «Фармація, промислова фармація» третього (освітньо-наукового) рівня вищої освіти за спеціальністю 226 «Фармація, промислова фармація» галузі знань 22 Охорона здоров'я, а також освітні програми для другого (магістерського) рівня освіти спеціальності 226 «Фармація, промислова фармація».

\section{1. Аналіз освітніх програм другого (магістерського) рівня освіти спеціальності 226 «Фармація, промислова фармація» \\ з закордонними 3 ВО}

У НУЛП підготовка студентів магістерського рівня освіти здійснюється за освітньо-професійною програмою (ОПП) терміном 1,5 роки навчання та за ОНП терміном 2 роки навчання. Порівняльний аналіз ОПП та ОНП з ЗВО України не проводився, оскільки особливістю нашого ЗВО є підготовка бакалаврського рівня освіти, на відміну від інших ЗВО, які випускають спеціалістів магістерського рівня освіти.

Аналіз ОПП та ОНП другого (магістерського) рівня освіти спеціальності 226 «Фармація, промислова фармація» проводився 3 метою порівняння та виявлення спільних та відмінних характеристик щодо обсягу навчального навантаження за групами компонентів та циклами підготовки ОПП університетів Європи та світу. Для проведення порівняльного аналізу ОПП були вибрані такі ОПП: "Master of Pharmaceutical Industry", The University of Queensland (Australia); "Industrial Pharmacy", Leiden University (Netherlands); "Pharmacy", University of Opole (Poland).

Перелік компонентів освітньої програми (назви дисциплін та кількість кредитів за ОПП) НУЛП та вищевказаних ЗВО представлено в таблиці 1.

Проведений аналіз дозволяє оцінити кредитну мобільність ОПП другого (магістерського) рівня освіти спеціальності 226 «Фармація, промислова фармація». Загальна кількість кредитів повністю співпадає в ОПП усіх університетів. В ОПП виділені окремі навчальні блоки, вказані назви окремих дисциплін. В ОПП University of Queensland значна частина кредитів відводиться на дисципліни, що стосуються виробництва фармацевтичних засобів: Основи фармацевтичної промисловості, ч.1 і 2 (8+8 кред.). Ці дисципліни $€$ відповідними блоку дисциплін нашої ОПП: Промислова технологія 
фармацевтичних виробництв, ч.1 і 2 (6+4 кред.), Промислове обладнання хіміко-фармацевтичних підприємств (3 кред.), Технологія і застосування лікувальних косметичних засобів (4 кред.).

Розглядаються питання, що регулюють фармацевтичне виробництво: Виробництво фармацевтичних препаратів, регуляторні питання та управління (2 кред.), Реєстрація лікарських засобів та менеджмент (2 кред.), Управління проєктами та комерціалізація у фармацевтичній промисловості (2 кред.). Ці питання розглядаються в дисциплінах ОПП НУЛП: Моделювання і проєктування хіміко-фармацевтичних підприємств у системі GMP (9 кред.) та Економіка хіміко-фармацевтичних підприємств (3 кред.). Значна увага приділяється розробці лікарських засобів (ЛЗ): Розробка ЛЗ (4 кред.), Клінічна розробка ЛЗ та біометрія (2 кред.), Доклінічна розробка ЛЗ (4 кред.). Однак більш розгорнуто питання розробки нових ЛЗ в НУЛП вивчаються на третьому (аспірантському) рівні освіти, але в курсі ОПП Наукові аспекти біофармації (4 кред.) розглядаються окремі питання, що стосуються розробки ЛЗ. Значна увага, як і в нашій ОПП, приділена виконанню індивідуальних дослідницьких проєктів: Незалежний дослідницький проєкт (16 кред.), Виконання кваліфікаційної роботи (32 кред.). В нашій ОНП є наступні дисципліни: Практика за темою магістерської кваліфікаційної роботи (9 кред.), Виконання магістерської кваліфікаційної роботи (16,5 кред.). Слід зазначити, що в ОПП University of Queensland зовсім не виділено кредитів на вивчення іноземної мови, навіть як вибіркової дисципліни.

В ОПП Leiden University (Netherlands) можна виділити дисципліну Основи належної виробничої практики (GMP) (2 кред.), яка $є$ частково відповідною дисципліні ОПП НУЛП: Моделювання і проєктування хіміко-фармацевтичних підприємств у системі GMP (9 кред.).

Є дисципліна Контроль якості ЛЗ (7 кред.), на яку в ОПП НУЛП відводиться 3 кред. Дисципліна Управління якістю у фармації та біотехнологіях (8 кред.) має відповідну в нашій ОПП: Оцінка якості ЛЗ (4 кред.). Вступний курс Біо-фармацевтичні науки (4 кред.) є відповідним курсу Наукові аспекти біофармації (4 кред.) нашої ОПП. Питання адресної доставки ліків розглядаються в курсі Доставка ліків (4 кред.), в нашій ОПП ці питання винесені до дисципліни Технологія біологічно-активних речовин, біомедполімерів і наноструктур (5 кред.). 
哭

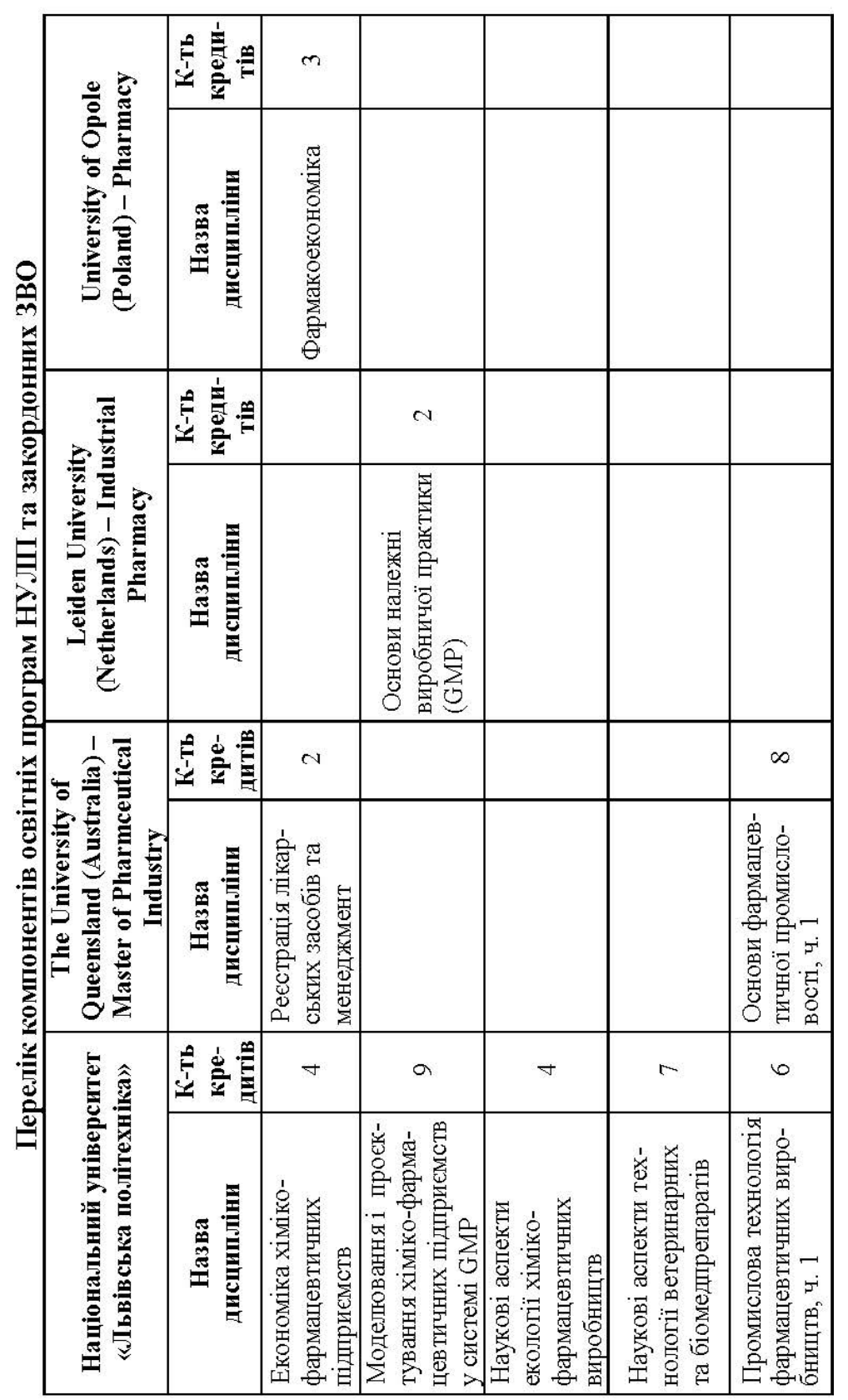




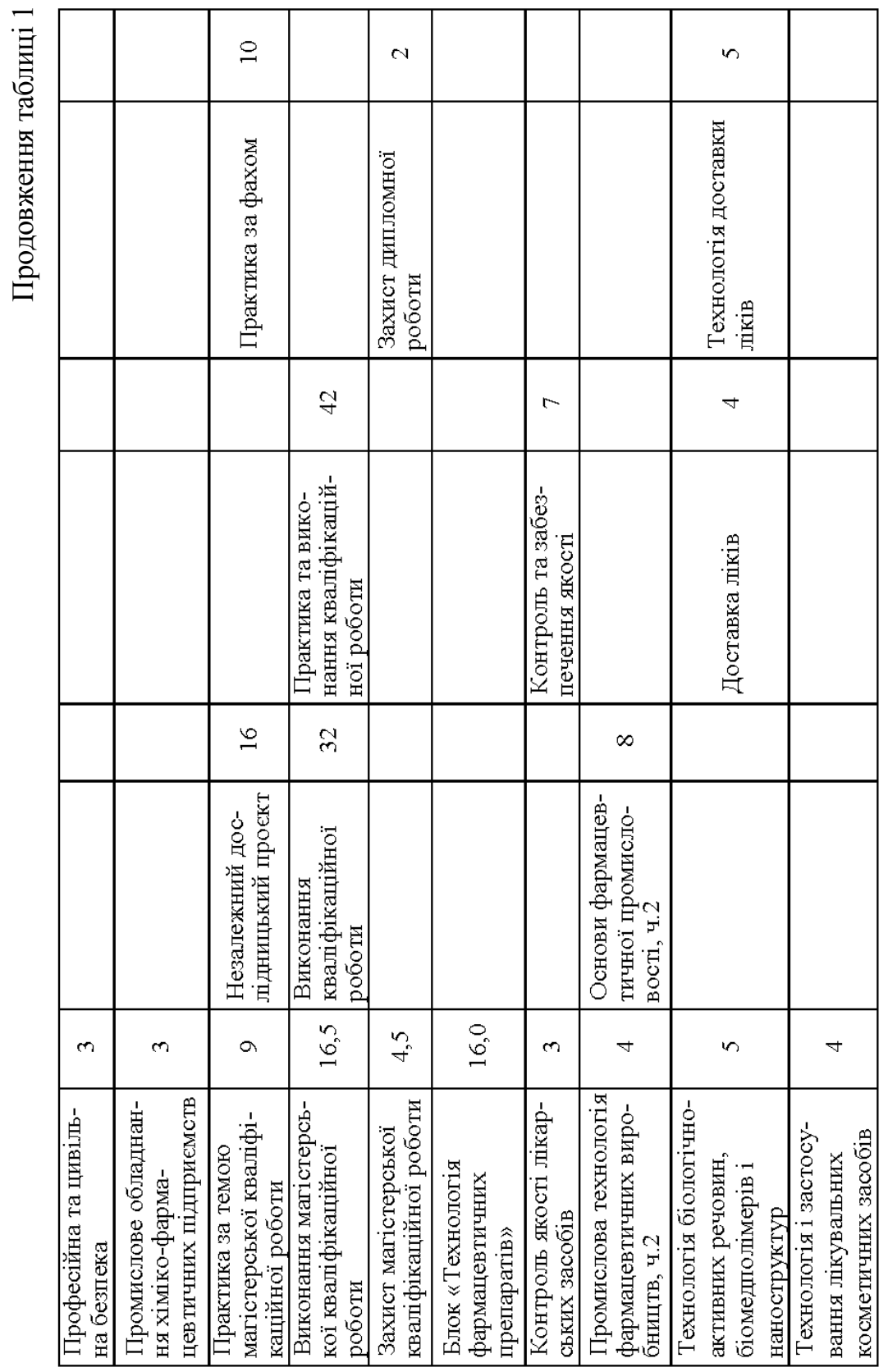




\begin{tabular}{|c|c|c|c|c|c|c|c|c|c|}
\hline & $m$ & $m$ & & & 0 & $m$ & $\mathrm{~N}$ & $m$ & $m$ \\
\hline & 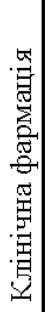 & 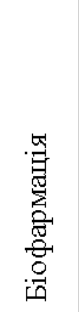 & & & 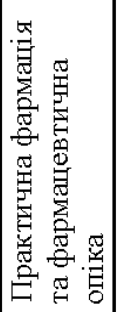 & 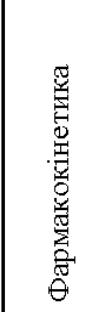 & 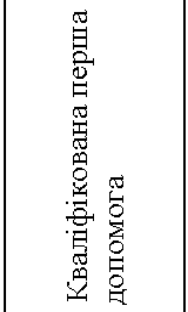 & 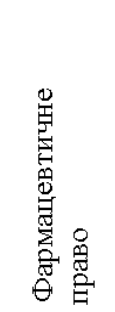 & 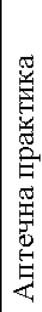 \\
\hline & & $\nabla$ & $\neg \infty$ & & $m$ & & & - & \\
\hline & & 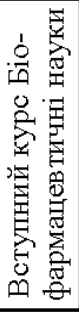 & 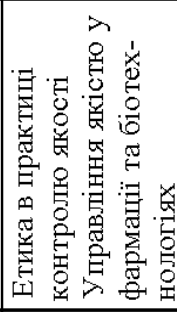 & & 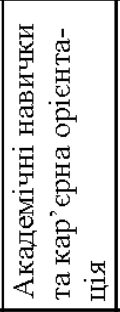 & & & 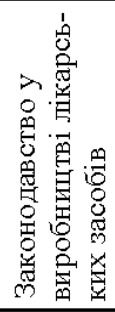 & \\
\hline & & $\nabla$ & $\mathrm{N}$ & & $\mathrm{N}$ & $\nabla$ & $\mathrm{N}$ & & \\
\hline & & 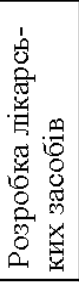 & 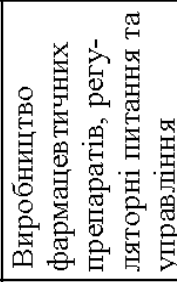 & & 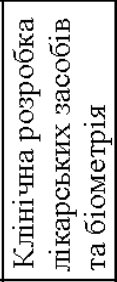 & 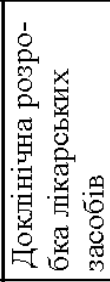 & 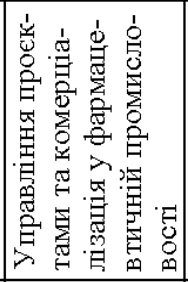 & & \\
\hline & $\nabla$ & $\nabla$ & $\forall$ & $\nabla$ & & & & & \\
\hline 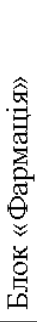 & 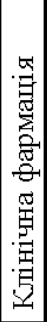 & 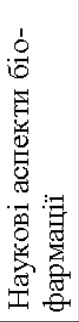 & 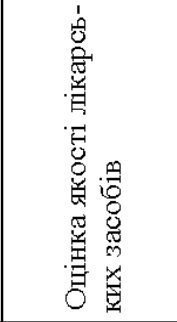 & 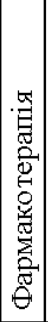 & & & & & \\
\hline
\end{tabular}




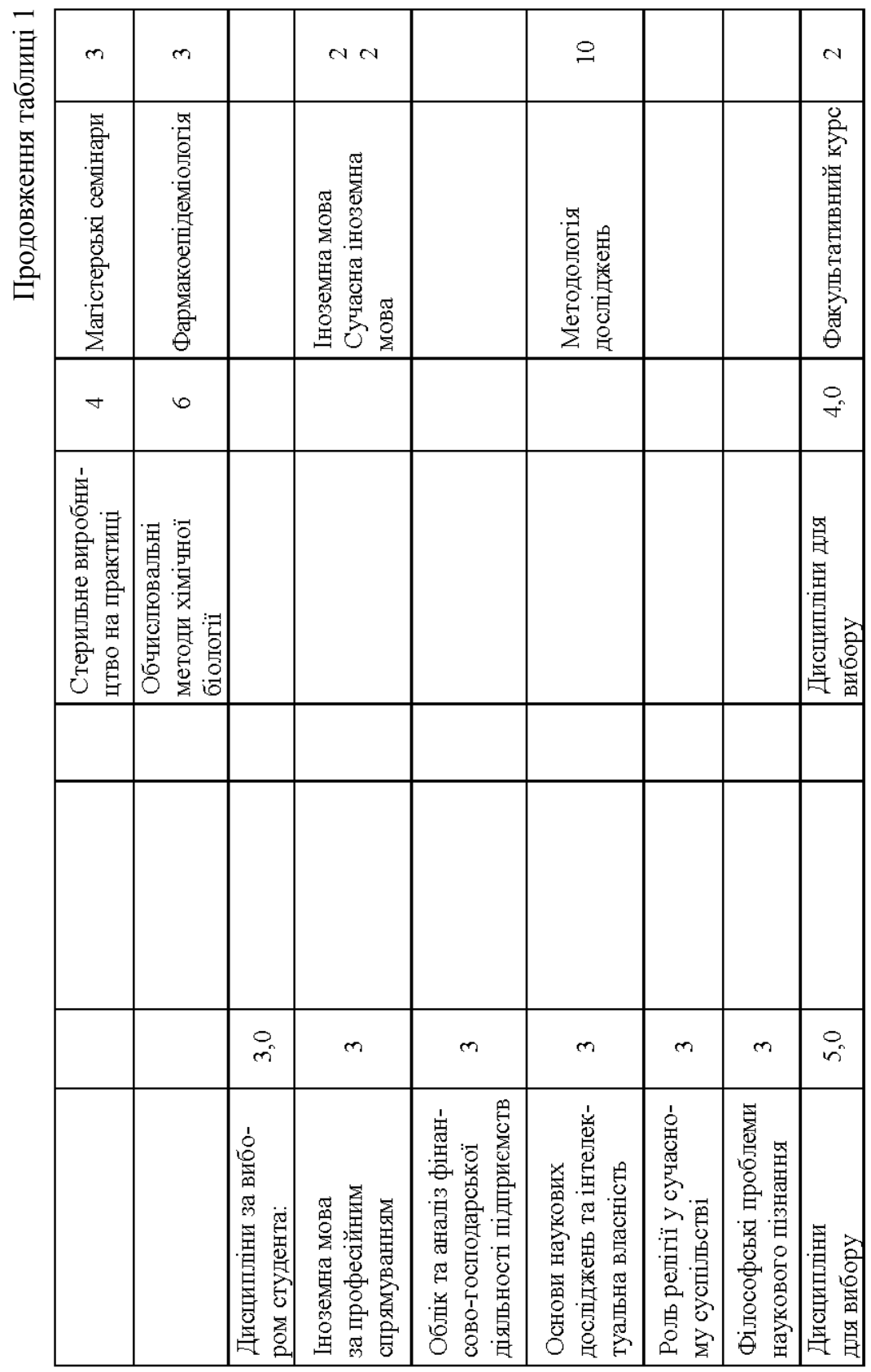


На виконання індивідуальної дослідницької роботи виділяється 42 кред.: Практика та виконання кваліфікаційної роботи. В нашій ОПП на це відводиться 25,5 кред. (9 кред. - Практика за темою магістерської кваліфікаційної роботи, 16,5 кред. - Виконання магістерської кваліфікаційної роботи).

В університеті вивчаються дисципліни Академічні навички та кар'єрна орієнтація (3 кред.), Етика в практиці контролю якості (1 кред.). Законодавство у виробництві Л3 (1 кред.). Стерильне виробництво на практиці (4 кред.) є частиною дисципліни нашої ОПП Промислова технологія фармацевтичних виробництв, ч.1 і 2 (6+ 4 кред.). Дисципліна Обчислювальні методи хімічної біології має 6 кред. В нашому університеті всі обчислювальні методи вивчаються на першому освітньому рівні бакалавр.

В ОПП University of Opole (Poland) $є$ дисципліна Фармакоекономіка (3 кред.), яка є відповідною дисципліні нашої ОПП Економіка хіміко-фармацевтичних виробництв (3 кред.). Дисципліна Клінічна фармація (3 кред.) відповідає дисципліні нашої ОПП Клінічна фармація (4 кред.), однак в University of Opole додатково вивчають дисципліну Практична фармація та фармацевтична опіка (6 кред.). Питання доставки ліків розглядаються в курсі Технологія доставки ліків (5 кред.), в нашій ОПП ці питання винесені до дисципліни Технологія біологічноактивних речовин, біомедполімерів i наноструктур (5 кред.). На виконання індивідуальної дослідницької роботи виділяється значно менше кредитів, ніж в інших університетах: Практика за фахом (10 кред.) і Захист дипломної роботи (2 кред.). Нагадаємо, що в нашій ОПП на це відводиться 25,5 кред. В блоці вибіркових дисциплін $є$ дисципліни Іноземна мова (2 кред.) і Сучасна іноземна мова (2 кред.), в нашій ОПП $є$ відповідна дисципліна Іноземна мова за професійним спрямуванням (3 кред.). Дисципліни Фармакокінетика та Аптечна технологія ліків вивчаються нашими студентами на бакалаврському рівні.

Значна увага приділяється проведенню наукових досліджень: Методологія досліджень (10 год), Магістерські семінари (3 кред.). В нашій ОПП $є$ дисципліна Основи наукових досліджень та інтелектуальна власність (3 кред.). Кожна 3 цих ОПП другого рівня освіти спеціальності 226 «Фармація, промислова фармація» має свої особливості та переваги. 


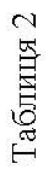

\begin{tabular}{|c|c|c|c|c|c|}
\hline \multirow[b]{2}{*}{ 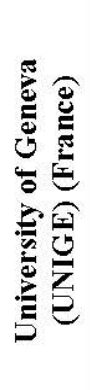 } & 息竞 & & & & \\
\hline & 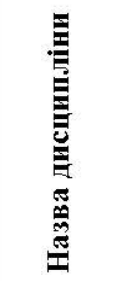 & & & & \\
\hline \multirow{2}{*}{ 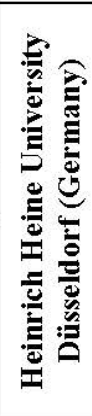 } & 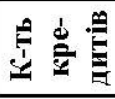 & $\mathrm{N}$ & $\mathrm{N}$ & & \\
\hline & 菣 & 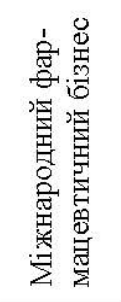 & 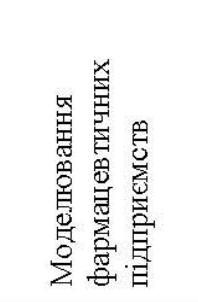 & & \\
\hline \multirow{2}{*}{ 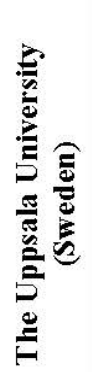 } & 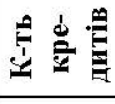 & & & & \\
\hline & 芦 & & & & \\
\hline \multirow{2}{*}{ 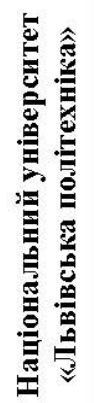 } & 息窇 & $\nabla$ & $a$ & $\nabla$ & $r$ \\
\hline & 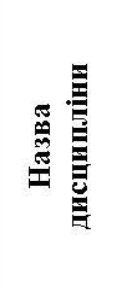 & 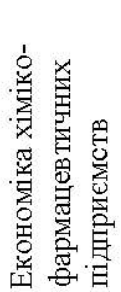 & 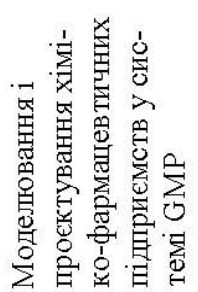 & 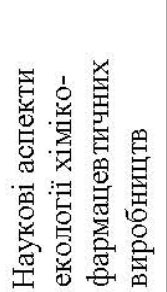 & 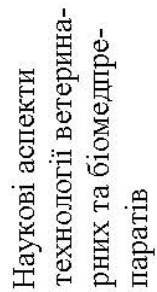 \\
\hline
\end{tabular}




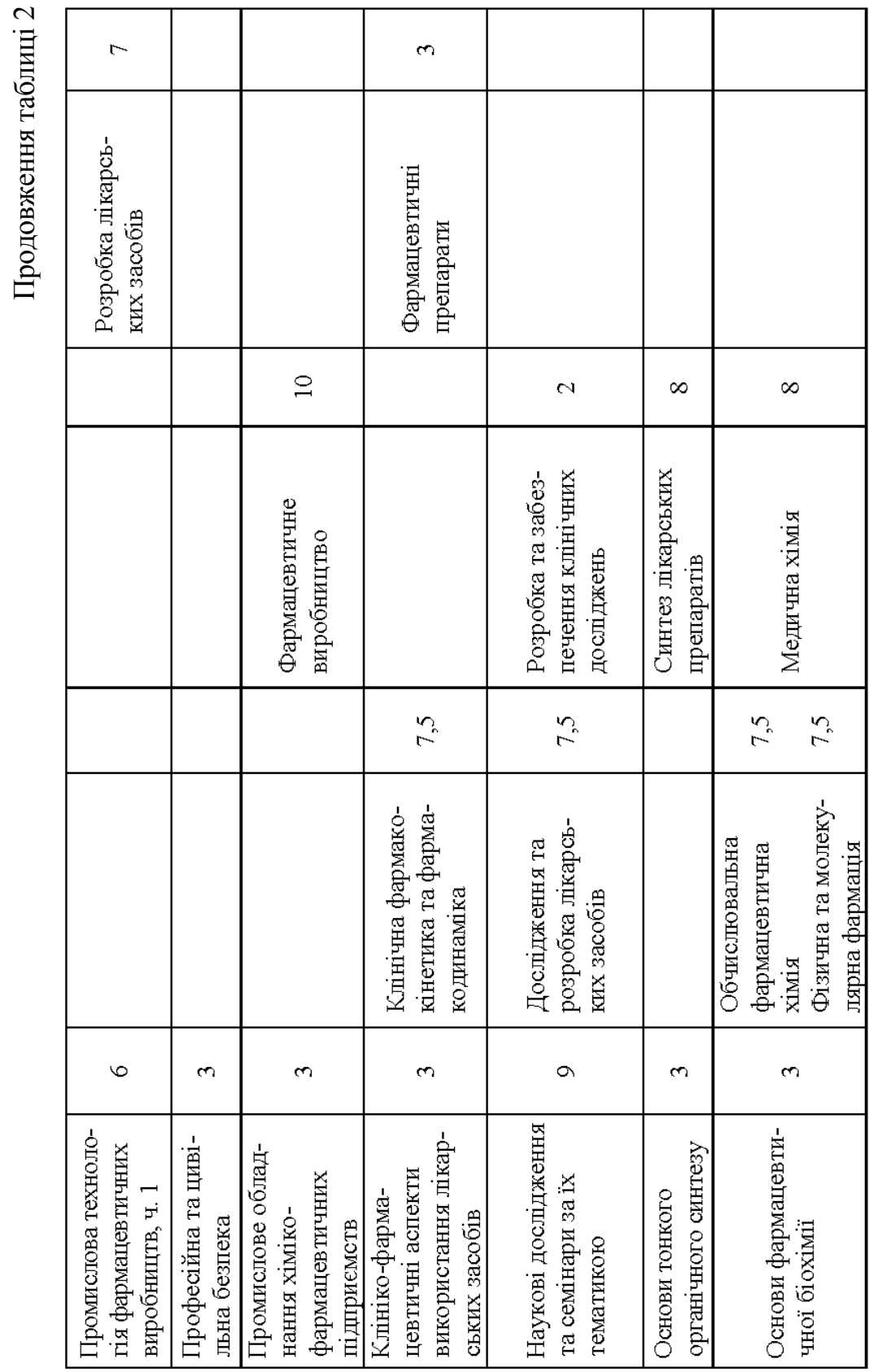




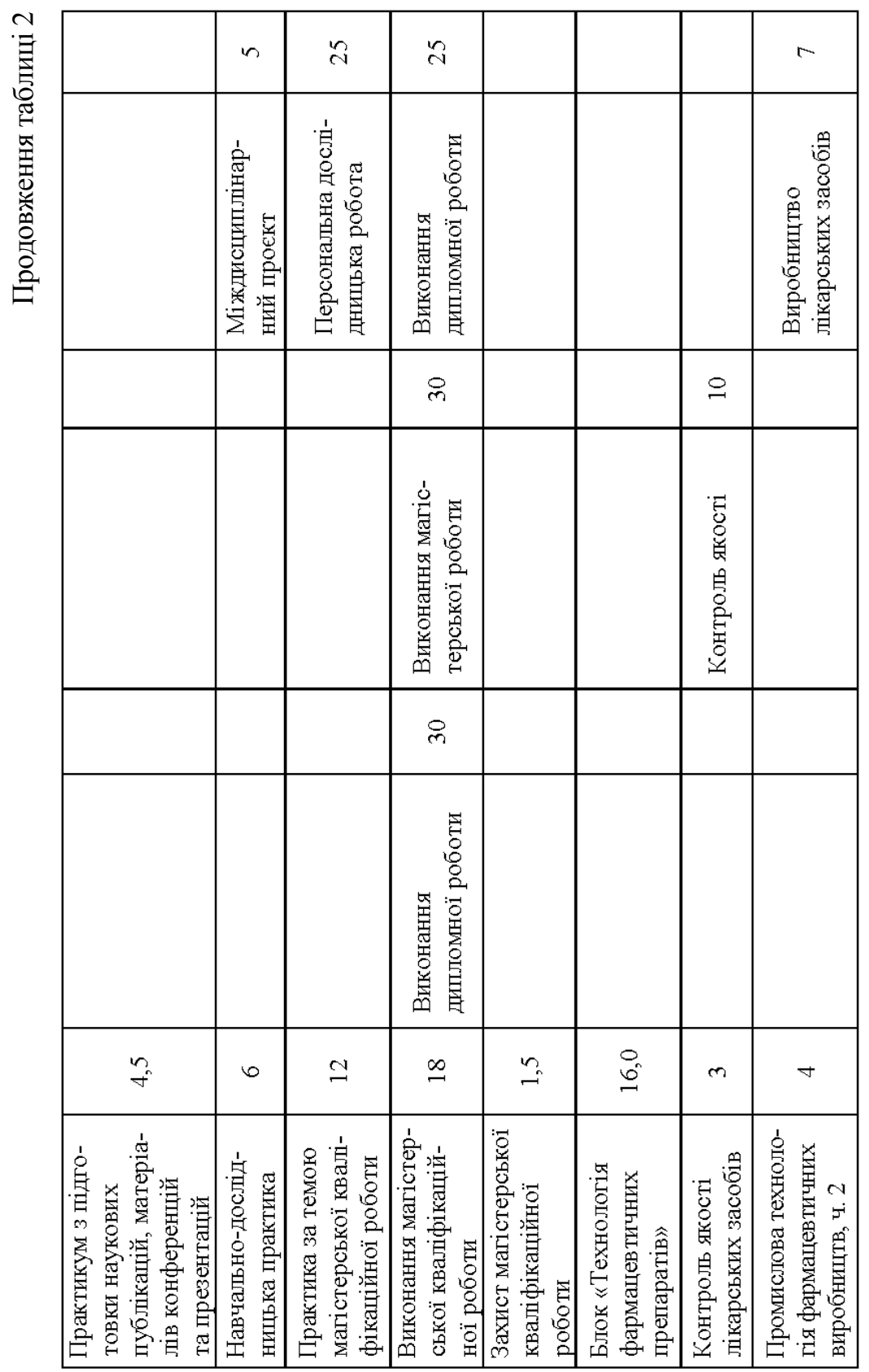




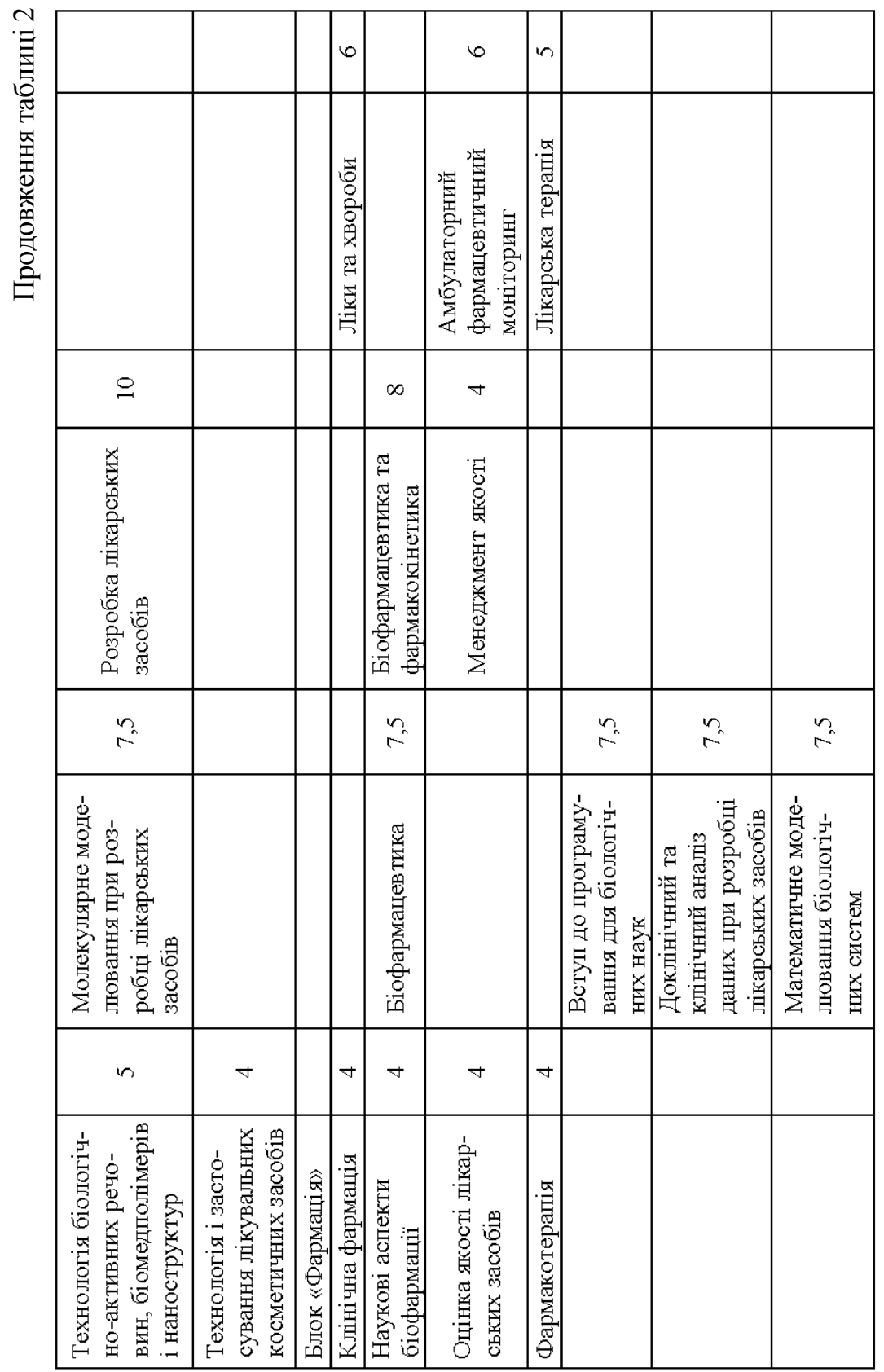




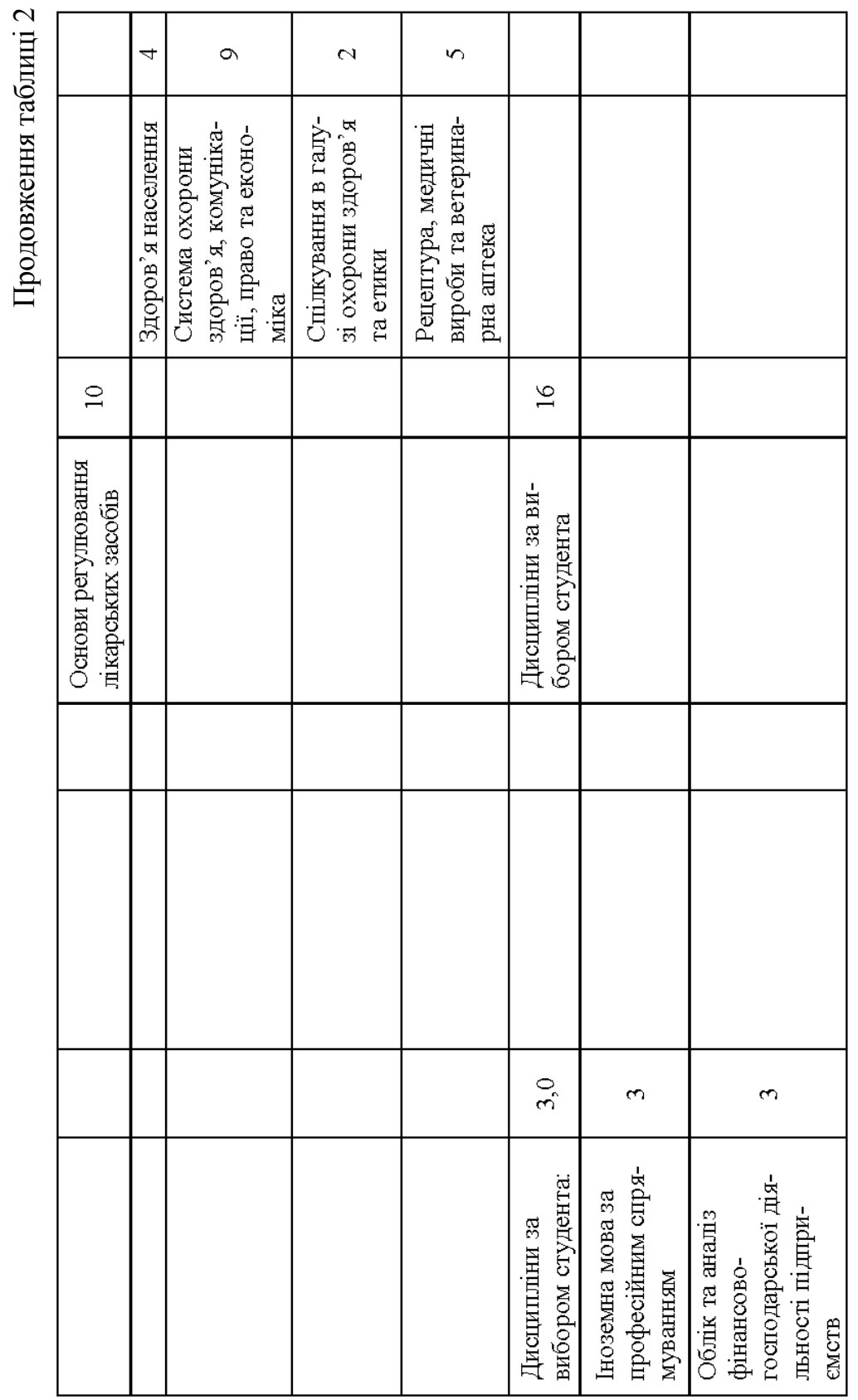




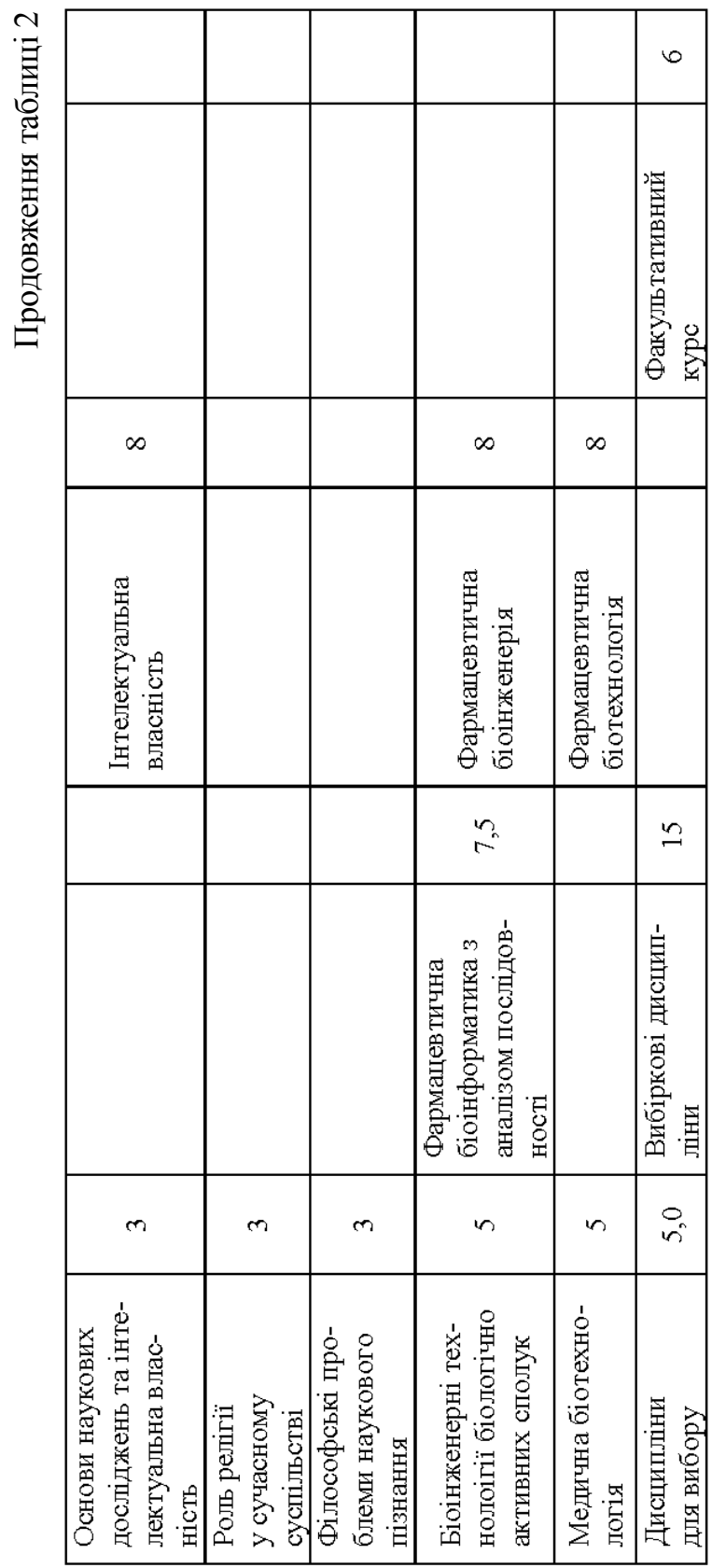


Для проведення порівняльного аналізу ОНП Другого рівня освіти (магістратура, 2 роки навчання) спеціальності 226 «Фармація, промислова фармація» були вибрані ОНП наступних університетів: The Uppsala University (Sweden); Heinrich Heine University Düsseldorf (Germany); University of Geneva (UNIGE) (Switzerland). Перелік компонентів освітньої програми: назви дисциплін та кількість кредитів за ОНП НУЛП та вказаних ЗВО представлено в таблиці 2.

Проведений нами аналіз дозволяє оцінити кредитну нобільність дисциплін ОНП другого (магістерського) рівня освіти спеціальності 226 «Фармація, промислова фармація». Загальна кількість кредитів повністю співпадає в ОНП усіх університетів. В усіх ОНП виділені окремі навчальні блоки, вказані назви окремих дисциплін.

В ОНП The Uppsala University (Sweden) значна частина кредитів відводиться на дисципліни, що стосуються поглибленого вивчення фармацевтичної хімії та біохімічних перетворень, з використанням статистичних методів: Біофармацевтика (7,5 кред.), Обчислювальна фармацевтична хімія (7,5 кред.), Фізична та молекулярна фармація (7,5 кред.), Фармацевтична біоінформатика 3 аналізом послідовності (7,5 кред.). В нашій ОНП є дисципліна Основи фармацевтичної біохімії (3 кред.), окремі питання розглядаються в курсах Наукові аспекти біофармації (4 кред.), Біоінженерні технології біологічно активних сполук (5 кред.) та Медична біотехнологія (5 кред.). Дисципліна Клінічна фармакокінетика та фармакодинаміка (7,5 кред.) має відповідну в нашій ОНП: Клініко-фармацевтичні аспекти використання лікарських засобів (3 кред.). Більша увага приділяється впровадженню комп'ютерних технологій: Вступ до програмування для біологічних наук (7,5 кред.), Математичне моделювання біологічних систем (7,5 кред.), Молекулярне моделювання при розробці лікарських засобів (7,5 кред.).

Багато уваги приділяється розробці лікарських засобів: Дослідження та розробка лікарських засобів (7,5 кред.), Доклінічний та клінічний аналіз даних при розробці лікарських засобів (7,5 кред.).

У нашій ОНП питання розробки ЛЗ розглядаються в дисциплінах Наукові аспекти технології ветеринарних та біомедпрепаратів (7 кред.), Наукові дослідження та семінари за їх тематикою (9 кред.), окремі аспекти розглядаються в дисциплінах 
Промислова технологія фармацевтичних виробництв, ч. 2 (4 кред.), Технологія біологічно-активних речовин, біомедполімерів i наноструктур (5 кред.). Однак поглиблено питання розробки ЛЗ вивчаються в НУЛП на третьому (аспірантському) рівні освіти. Значна увага, як і в нашій ОНП, приділена виконанню індивідуальних дослідницьких проєктів: Виконання дипломної роботи (30 кред.). В нашій ОНП є наступні дисципліни: Практика за темою магістерської кваліфікаційної роботи (12 кред.), Виконання магістерської кваліфікаційної роботи (18 кред.), Захист магістерської кваліфікаційної роботи (1,5 кред.). Зовсім не виділено кредитів на вивчення іноземної мови.

В ОНП Heinrich Heine University Düsseldorf (Germany) можна виділити багато дисциплін, які є відповідними дисциплінам ОНП НУЛП: дисципліні Міжнародний фармацевтичний бізнес (2 кред.) $є$ відповідною в нашій ОНП дисципліна Економіка хімікофармацевтичних підприємств (4 кред.); дисципліні Моделювання фармацевтичних підприємств (2 кред.) є відповідною в нашій ОНП дисципліна Моделювання і проєктування хіміко-фармацевтичних підприємств у системі GMP (9 кред.); дисципліні Фармацевтичне виробництво (10 кред.) є відповідним блок дисциплін Промислова технологія фармацевтичних виробництв, ч.1 і 2 (6+4 кред.) i Промислове обладнання хіміко-фармацевтичних підприємств (3 кред.); дисципліні Синтез лікарських препаратів (8 кред.) $\epsilon$ відповідною дисципліна Основи тонкого органічного синтезу (3 кред.); дисципліні Медична хімія (8 кред.) є відповідною Основи фармацевтичної біохімії (3 кред.); дисципліні Контроль якості (10 кред.) відповідною $є$ Контроль якості ЛЗ (3 кред.); дисципліні Менеджмент якості (4 кред.) відповідною є Оцінка якості ЛЗ (4 кред.); дисципліні Біофармацевтика та фармакокінетика (8 кред.) відповідною є Наукові аспекти біофармації (4 кред.); дисципліні Фармацевтична біоінженерія (8 кред.) відповідною є Біоінженерні технології біологічно активних сполук (5 кред.); дисципліні Фармацевтична біотехнологія (8 кред.) відповідною $є$ Медична біотехнологія (5 кред.); дисципліні Інтелектуальна власність (8 кред.) відповідною $є$ Основи наукових досліджень та інтелектуальна власність (3 кред.). $С$ окрема дисципліна Розробка Л3 (10 кред.) і дисципліна Основи регулювання ЛЗ (10 кред.). На виконання магістерської роботи виділяється 30 кред. Зовсім не виділено кредитів на вивчення іноземної мови. 
В ОНП University of Geneva (UNIGE) (Switzerland) є дисципліна Лікарська терапія (5 кред.), яка $є$ відповідною дисципліні нашої ОПП Фармакотерапія (4 кред.); дисципліна Ліки та хвороби (6 кред.) є відповідною Клінічна фармація (4 кред.); дисципліні Виробництво ЛЗ (7 кред.) відповідним $є$ блок дисциплін Промислова технологія фармацевтичних виробництв, ч. 1 і 2 (6+4 кред.) i Промислове обладнання хіміко-фармацевтичних підприємств (3 кред.); дисциплінам Фармацевтичні препарати (3 кред.) та Амбулаторний фармацевтичний моніторинг (6 кред.) відповідними є дисципліни Клініко-фармацевтичні аспекти використання Л3 (3 кред.) і Оцінка якості Л3 (4 кред.). Великий блок дисциплін стосується системи охорони здоров'я: Здоров'я населення (4 кред.), Система охорони здоров'я, комунікації, право та економіка (9 кред.), Спілкування в галузі охорони здоров'я та етики (2 кред.). На виконання індивідуальної дослідницької роботи виділяється більше кредитів, ніж в інших університетах: Міждисциплінарний проєкт (5 кред.), Персональна дослідницька робота (25 кред.), Виконання дипломної роботи (25 кред.).

ОНП вибраних університетів дуже сильно відрізняються, мають свої особливості та переваги. ОНП Heinrich Heine University Düsseldorf (Germany) в частині, що стосується вибору дисциплін і розподілу кредитів, має багато спільного з нашою ОНП другого (магістерського) рівня освіти спеціальності 226 «Фармація, промислова фармація».

\section{2. Аналіз ОНП третього (аспірантського) рівня освіти спеціальності 226 «Фармація, промислова фармація» ЗВО в Україні та за кордоном}

Аналіз ОНП третього рівня освіти спеціальності 226 «Фармація, промислова фармація» проводився 3 метою порівняння та виявлення спільних та відмінних характеристик щодо структури, змісту та наповнення ОНП різних ЗВО України та ближнього зарубіжжя.

Порівняльний аналіз ОНП не мав на меті виокремлення певних структур змістових і структурологічних побудов та залучення їх чи поповнення ними власної ОНП. Проведений нами аналіз дозволяє оцінити 3 точки зору потенційного аспіранта прозорість та доступність ОНП (академічну доброчесність) та розуміння рівня можливості здійснення пошуку ОНП, яка відповідатиме науковим інтересам окремого аспіранта як здобувача-дослідника. 
3 метою проведення аналізу нами було взято ОНП лише 3 офіційних сайтів 3ВО: Тернопільський Національний медичний університет імені І.Я. Горбачевського МОЗ України (2019р.), НФаУ м. Харків (2019 р.), Харківська медична академія післядипломної освіти (2017р.), Національна медична академія післядипломної освіти імені П.Л. Шупика (2016р.), Івано-Франківський національний медичний університет (2016 р.), а також відомості про самооцінювання Львівський національний медичний університет імені Данила Галицького (2020 р.) (табл. 3, табл. 4).

В ОНП Національної медичної академії післядипломної освіти імені П.Л. Шупика (2016 р.) вказано розподіл кредитів (загалом 53 кред.) за окремими компетентностями та навчальними блоками, однак не вказано назви окремих дисциплін. На наш погляд, така структура пояснюється тим, що даний ЗВО має потужну наукову базу та може проводити різнопланову підготовку студентів, враховуючи напрям дисертаційного дослідження.

ОНП Івано-Франківського національного медичного університету (2016 р.) відрізняється наявністю змісту, вступу та нормативних посилань, що дозволяє легко зорієнтуватись у структурі освітньої програми та у нормативно-правовій базі, яка регламентує положення, згідно з якими створювалась ця ОНП. Представлено розподіл обсягу програми за видами навчальної діяльності, де вказано назви предметів та кредити, при виділенні з загального обсягу в 60 ЄКТС на дисципліни вільного вибору - 12 кред. ОНП Івано-Франківського національного медичного університету виділяється серед інших ОНП ЗВО чітким формулюванням положень та цілісним сприйняттям, що, на нашу думку, забезпечено введенням в робочу групу двох професорів мовознавства.

ОНП Харківської медичної академії післядипломної освіти (2017 р.) дуже вдало представлено (у таблицях) матриці компетентностей, однак у загальній характеристиці ОНП вказано як спеціалізації шифри попередніх спеціальностей 15.00.01 та 15.00.02, що, на нашу думку, не є доречним. Також в ОНП не вказані навчальні дисципліни та, відповідно, не встановлено обсяг навчання за кредитами. ОНП Тернопільського Національного медичного університету імені І.Я. Горбачевського МОЗ України (2019 р.) містить по тексту дві спеціальності 226 «Фармація», 226 «Фармація, промислова фармація», що є невірним. Однак в ОНП чітко вказано перелік компонент та їх логічна послідовність, наведено назви дисциплін та їх обсяги за кредитами. 
ОНП НФаУ м. Харків (2019 р.) представлена на офіційному сайті ЗВО не в повному обсязі, а у вигляді стислого інтернет-фейсу 3 зазначенням гаранта програми та його контактів, особливостей ОНП, компонентами програми (дисципліни), вказано перспективи працевлаштування за КВЕД ДК 009-2010, а також програмними результатами навчання. На нашу думку, така лаконічна подача інформації для потенційного аспіранта є дуже вдалою.

Відомості про самооцінювання Львівського національного медичного університету імені Данила Галицького (2020 р.) нами не аналізувались, оскільки до уваги ми брали ОНП 3ВО, які можна було отримати за умови віддаленого доступу, а на офіційному сайті даного ЗВО ОНП нами не було знайдено.

Опрацювання ОНП українських ЗВО дозволяє стверджувати про їх незначну відмінність навіть за умови відсутності стандарту.

Порівняльний аналіз ОНП ЗВО спеціальності 226 «Фармація, промислова фармація» 3 програмами іноземних ЗВО дозволив нам встановити певні відмінності. 3 метою проведення аналізу нами було взято інформацію лише з офіційних сайтів ЗВО: Варшавського медичного університету (2015 р.), Медичного університету Любліна (2018-2019 рр.), а також Бруклінського фармацевтичного коледжу Університету Лонг-Айленду (США) (2019р.), Іллінойського університету (Чикаго, США) (2020р.) (табл. 5, табл. 6).

Інформаційний сайт Варшавського медичного університету (2015 р.) містив інформацію про: Стандарт освіти, для студента, що готується до роботи фармацевта, а також окремо інформаційний сайт щодо результатів навчання в докторантурі на фармацевтичному факультеті; рамки для стаціонарних досліджень докторантів на фармацевтичному факультеті в системі ECTS; Система управління якістю освіти Варшавського медичного університету.

Інформаційний сайт Медичного університету Любліна (20182019 рр.) містить інформацію щодо форми навчання на факультеті Формації та медичної аналітики, терміну навчання (3 роки, 6 семестрів) та документів, які необхідно подати для вступу. Вказано термін подачі документів, адреса для подачі документів та контактний телефон. Також до вищевказаних документів прикріплена таблиця з предметами передбаченими ОНП. В ній окремими блоками подано обов'язкові, фахові та вибіркові дисципліни, професійна практика, вказано обсяги навчання в годинах та кредитах. 


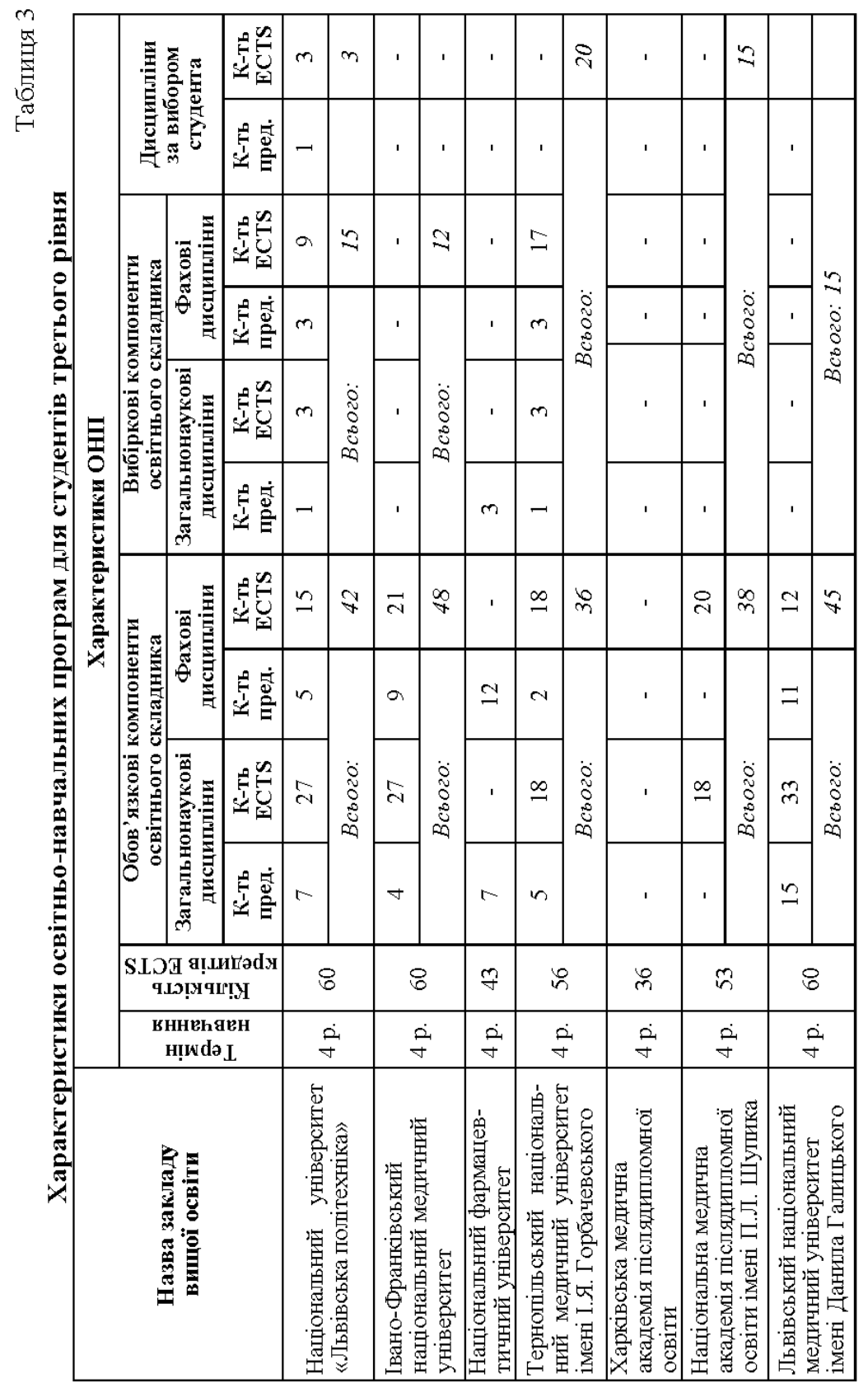




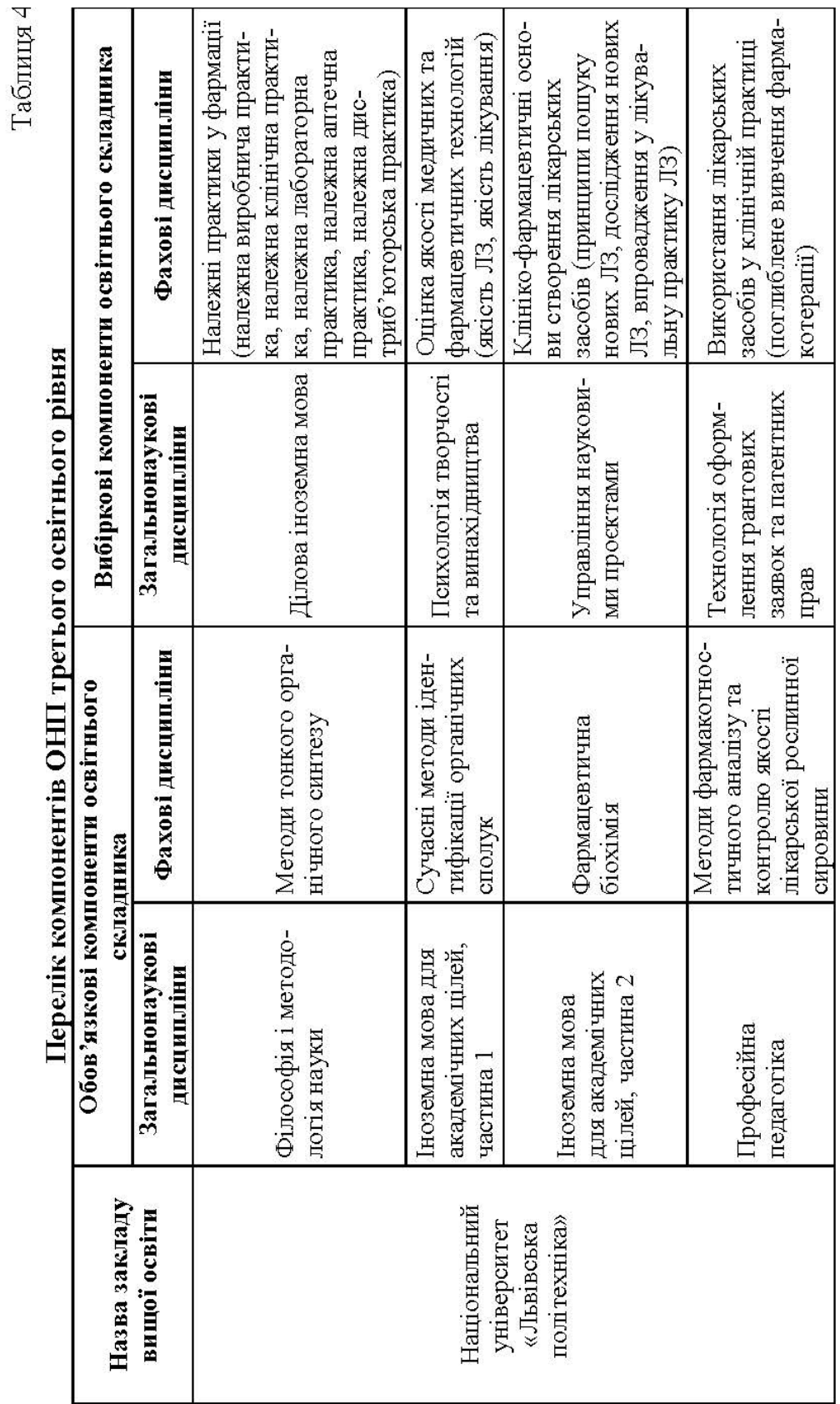




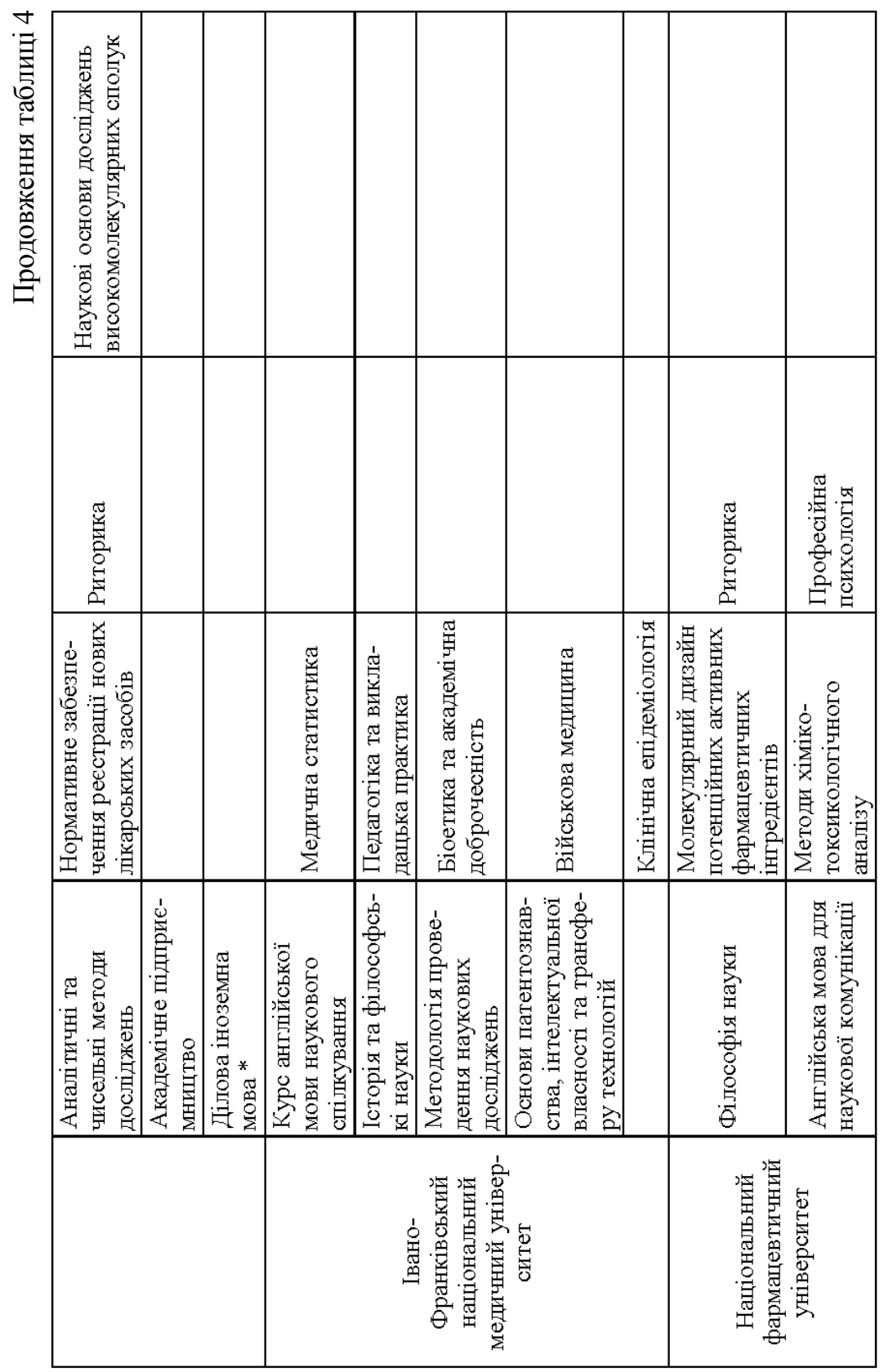




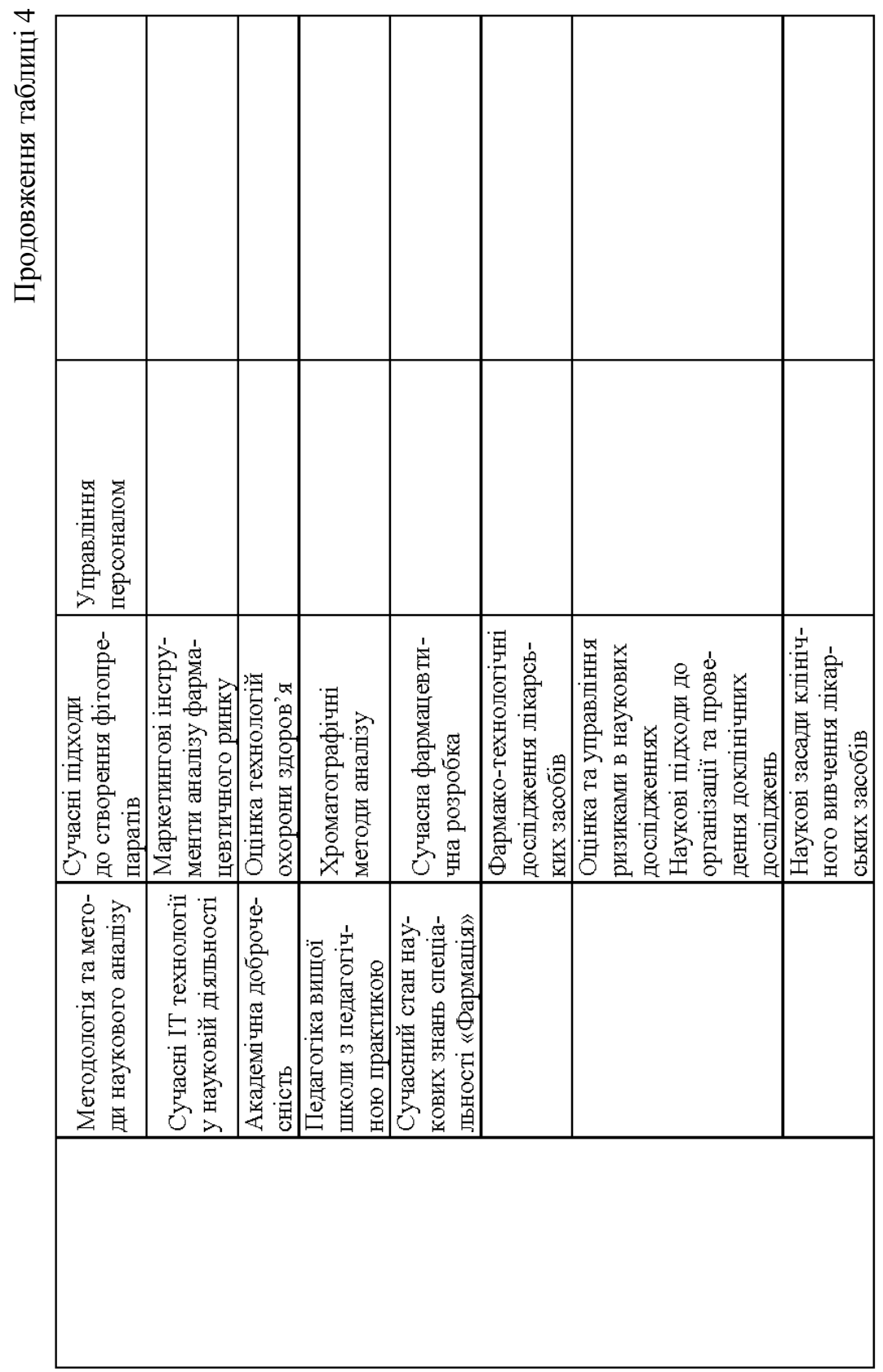




\begin{tabular}{|c|c|c|c|c|c|c|}
\hline & 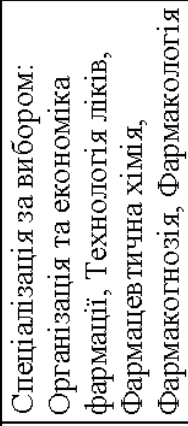 & 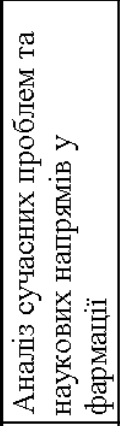 & 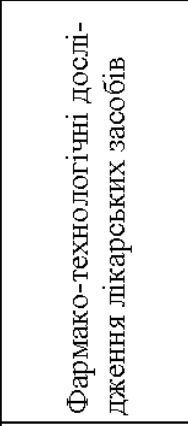 & 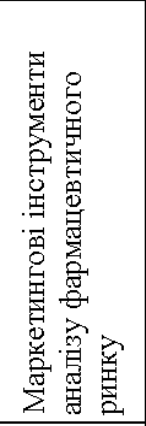 & 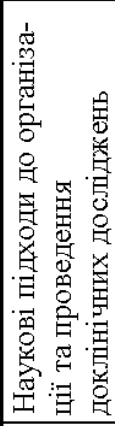 & 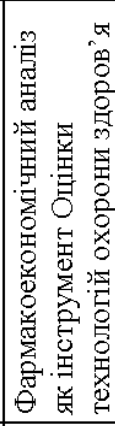 \\
\hline & 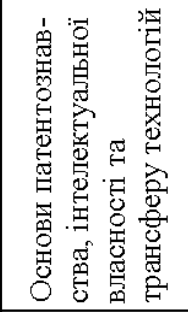 & 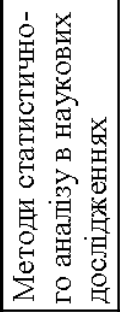 & 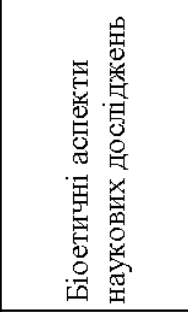 & 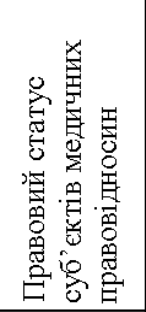 & 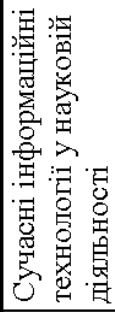 & 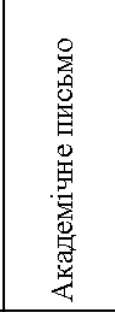 \\
\hline 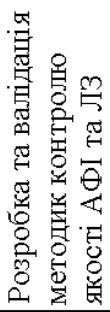 & 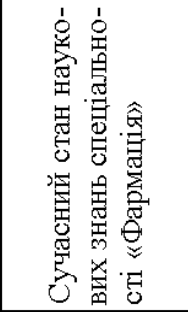 & 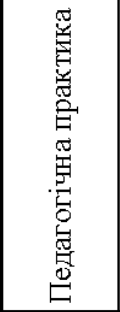 & & & & \\
\hline & 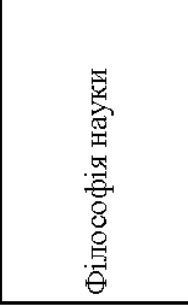 & 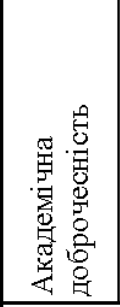 & 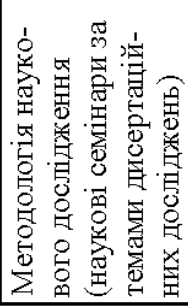 & 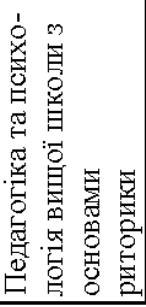 & 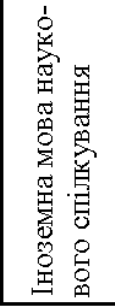 & \\
\hline & 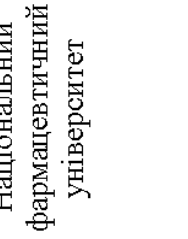 & & 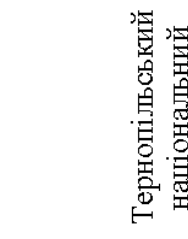 & 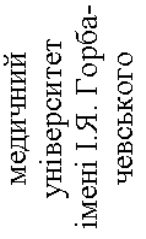 & & \\
\hline
\end{tabular}




\begin{tabular}{|c|c|c|c|c|c|c|c|c|c|}
\hline 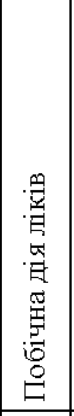 & 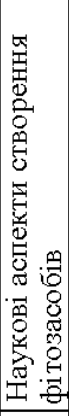 & 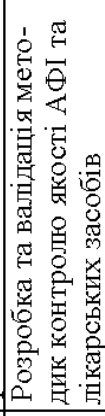 & 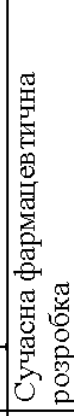 & 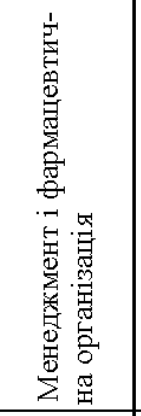 & 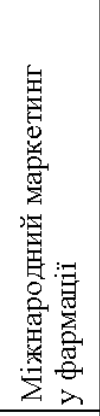 & 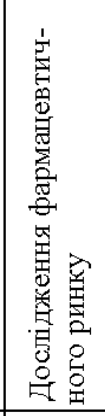 & 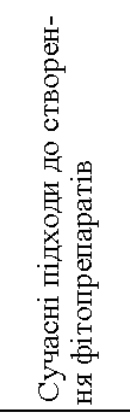 & 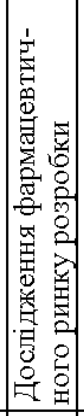 & \\
\hline \multirow[t]{4}{*}{ 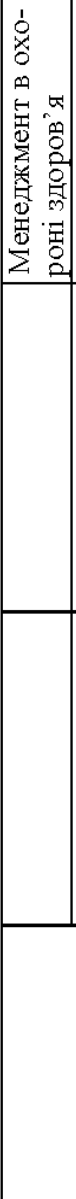 } & 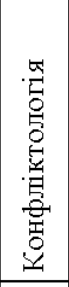 & & & 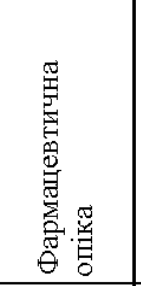 & 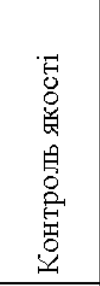 & 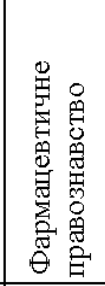 & 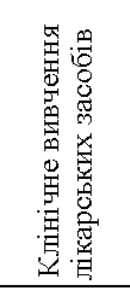 & 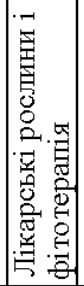 & \\
\hline & & & & 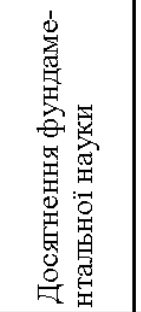 & 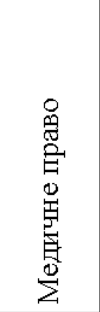 & 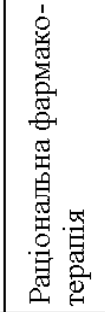 & 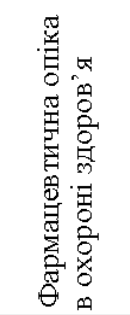 & 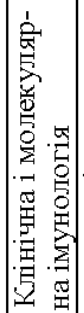 & 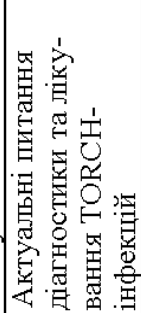 \\
\hline & & & & 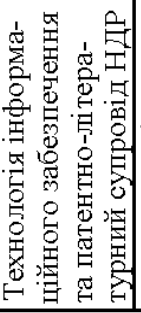 & 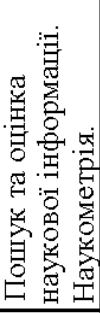 & 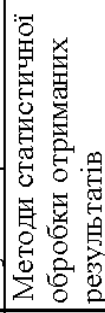 & 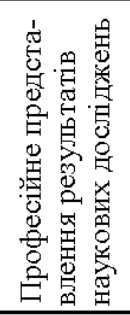 & 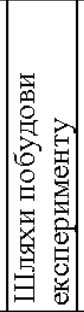 & 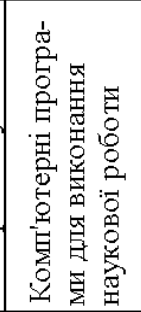 \\
\hline & \multicolumn{5}{|c|}{ 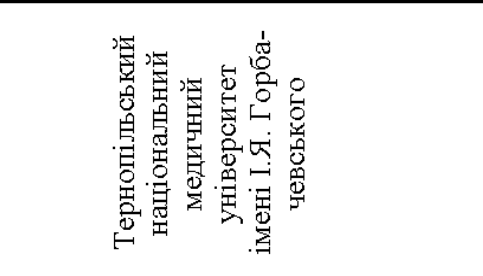 } & 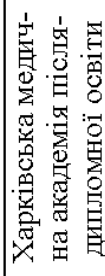 & 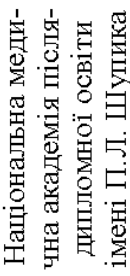 & & \\
\hline
\end{tabular}




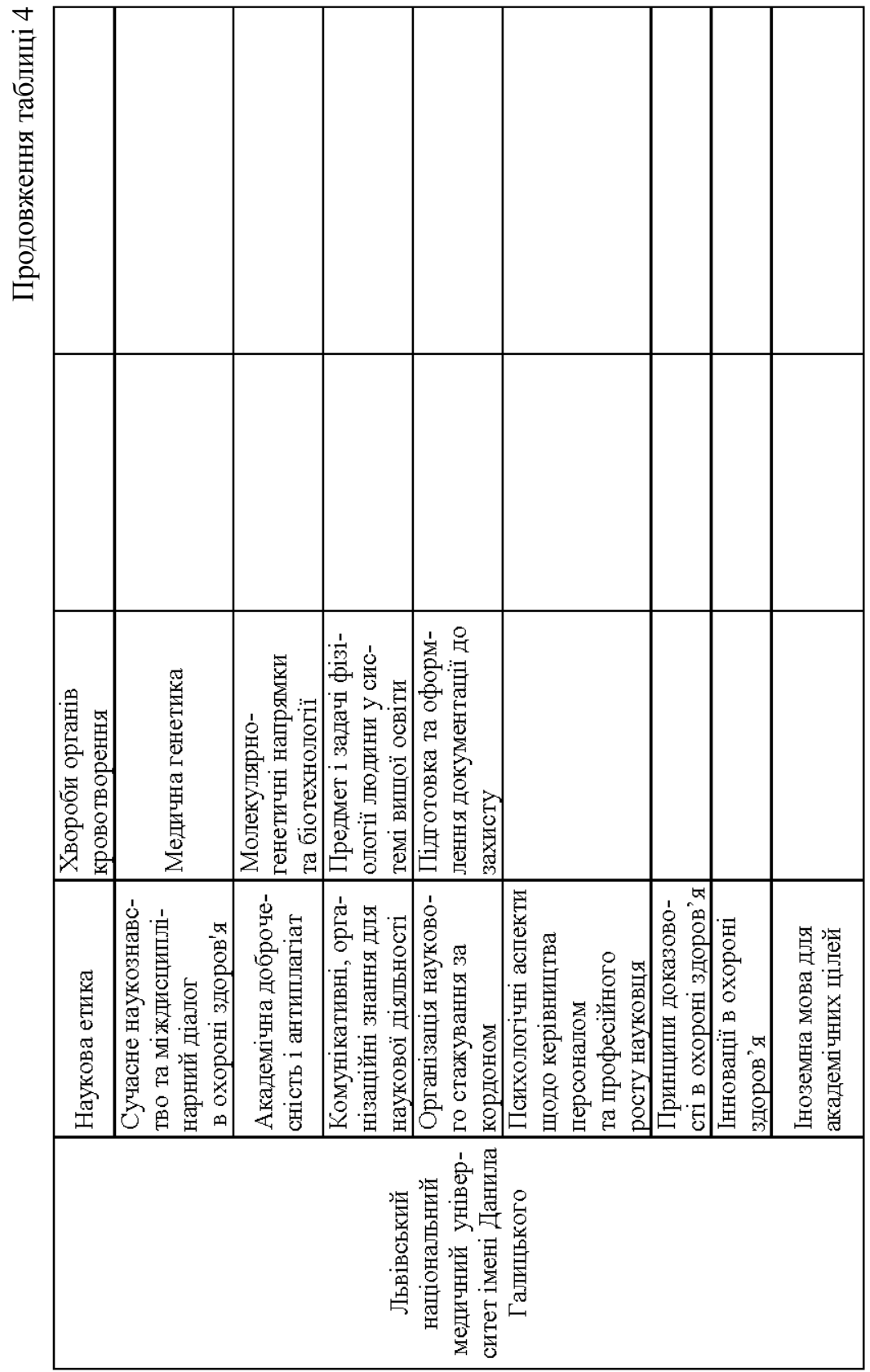


昆

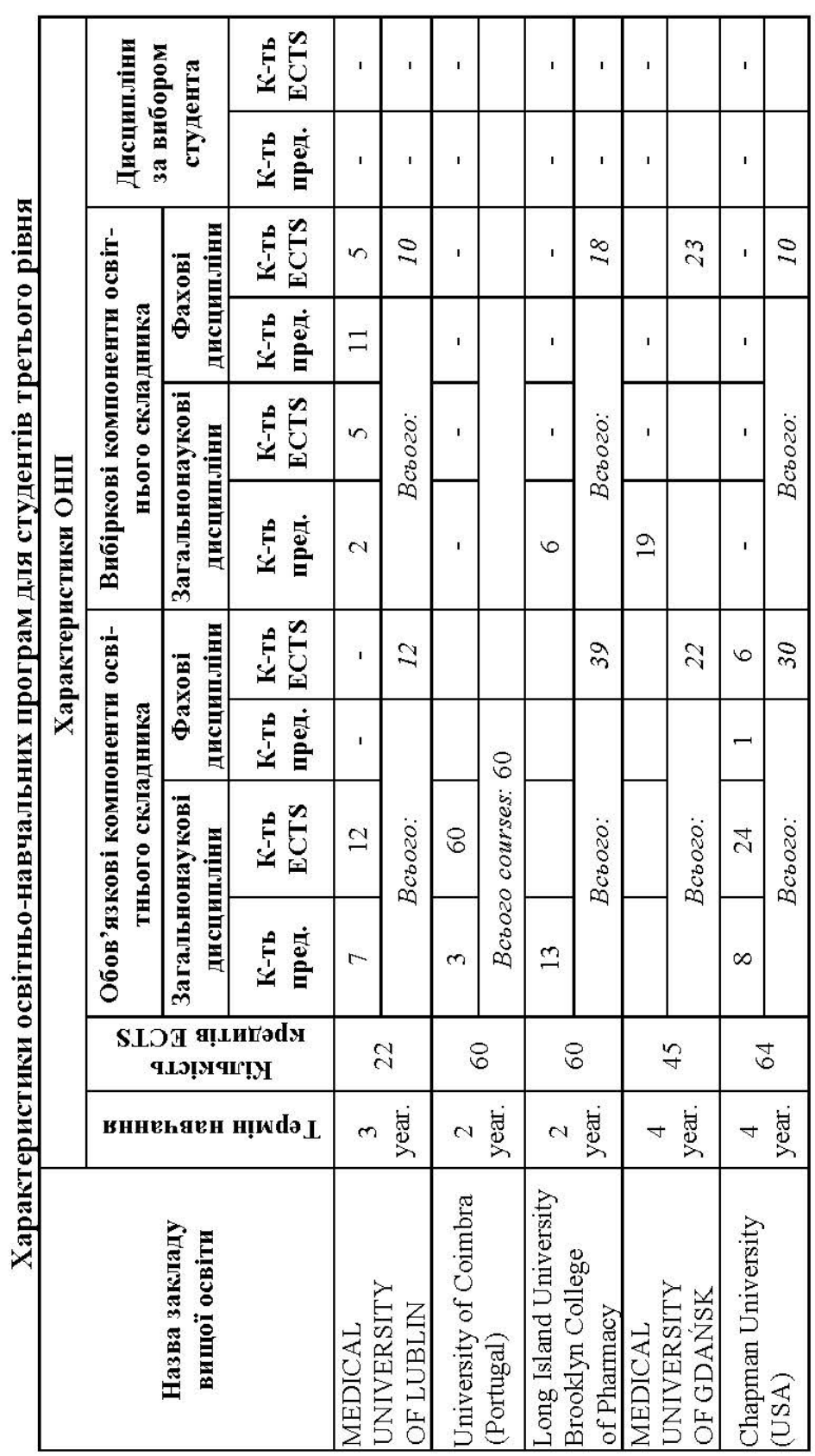


업

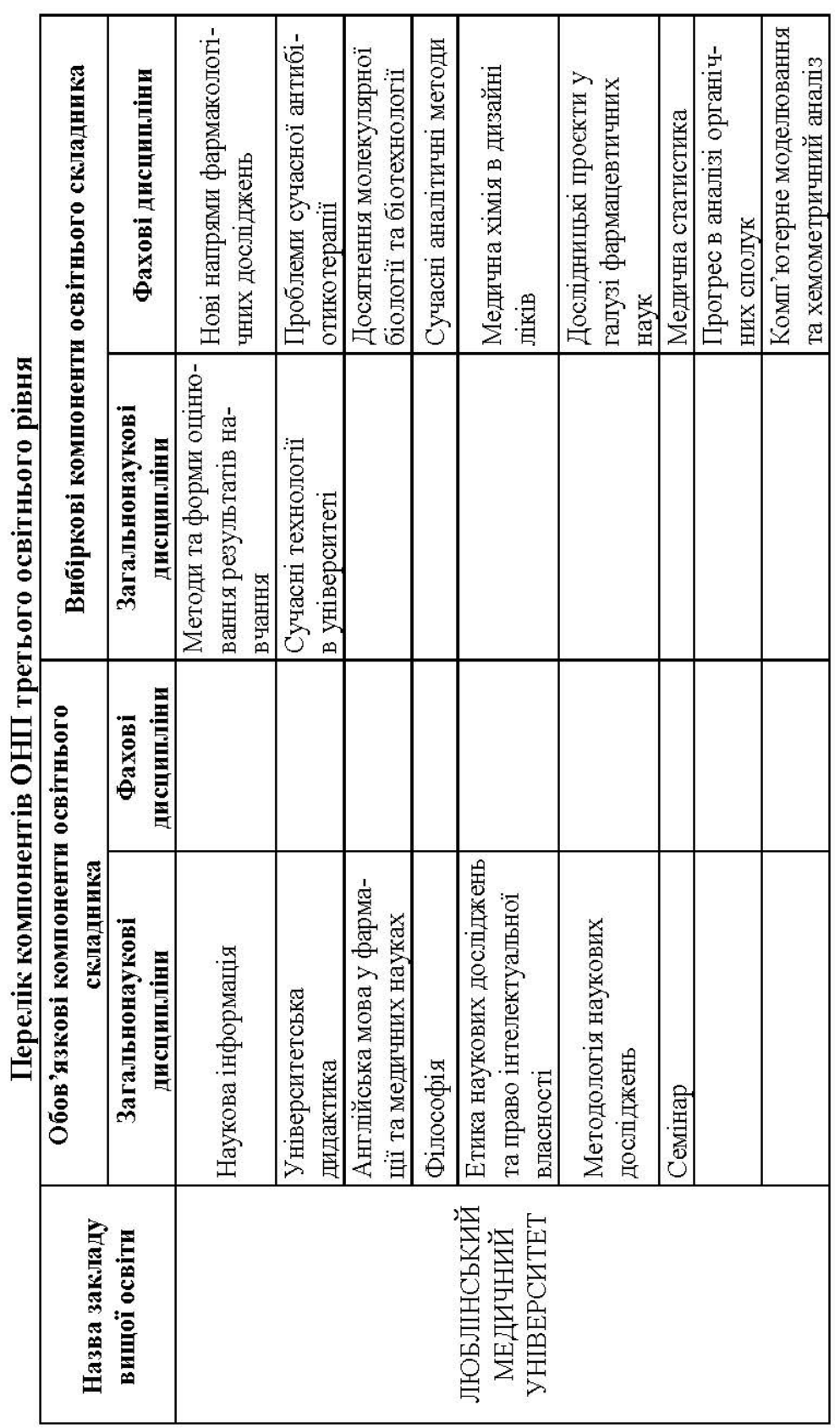




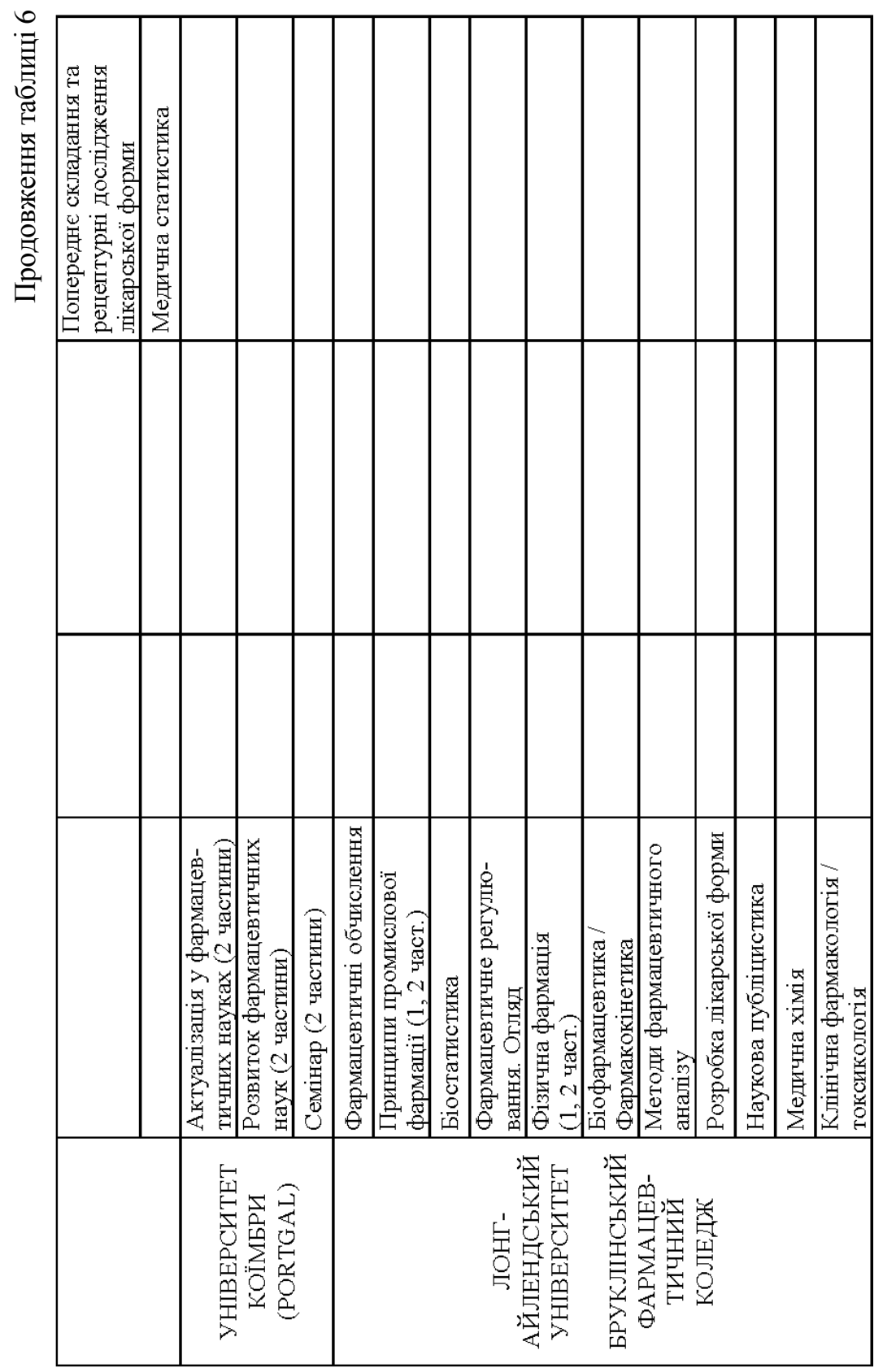




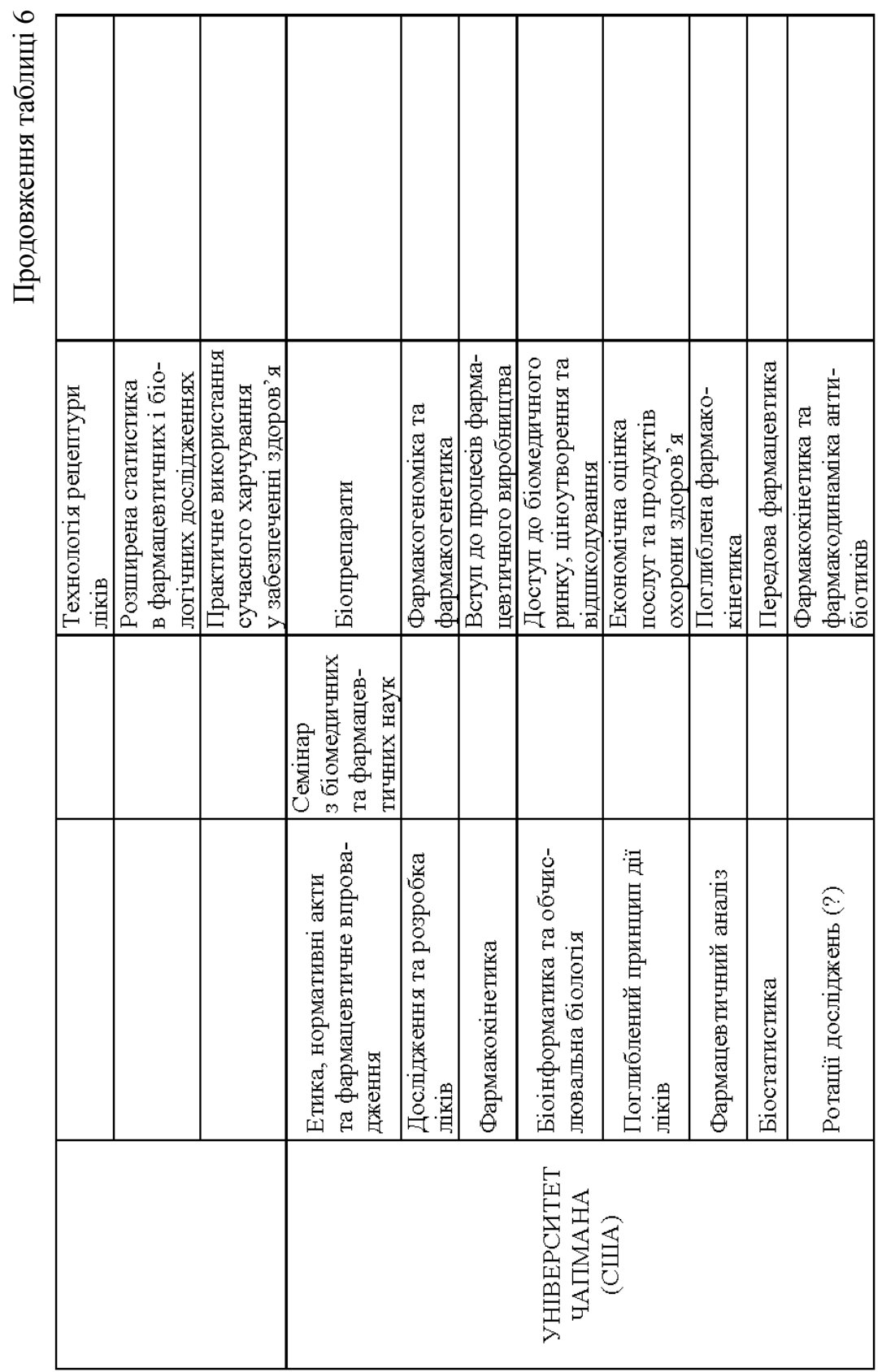




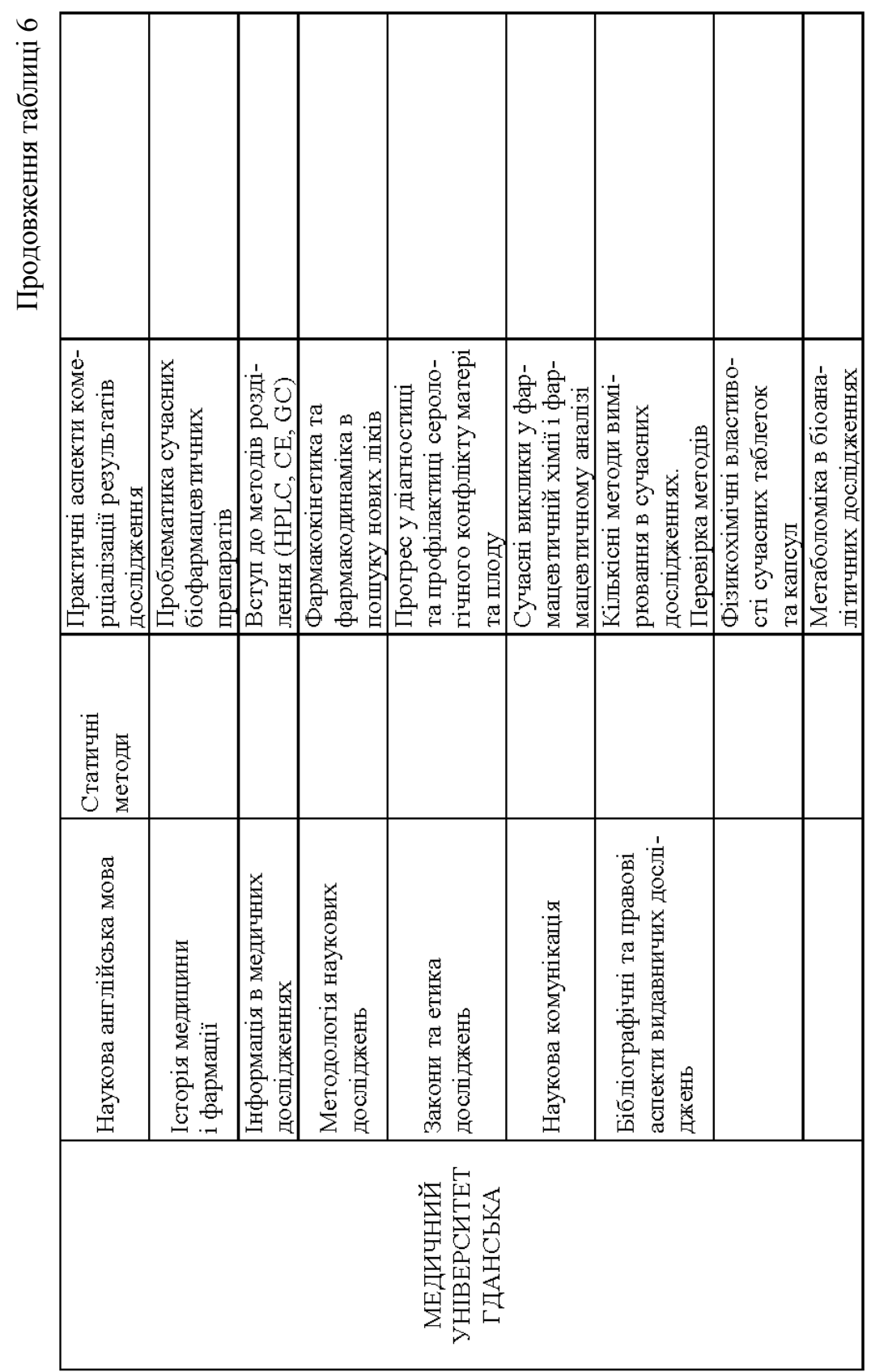



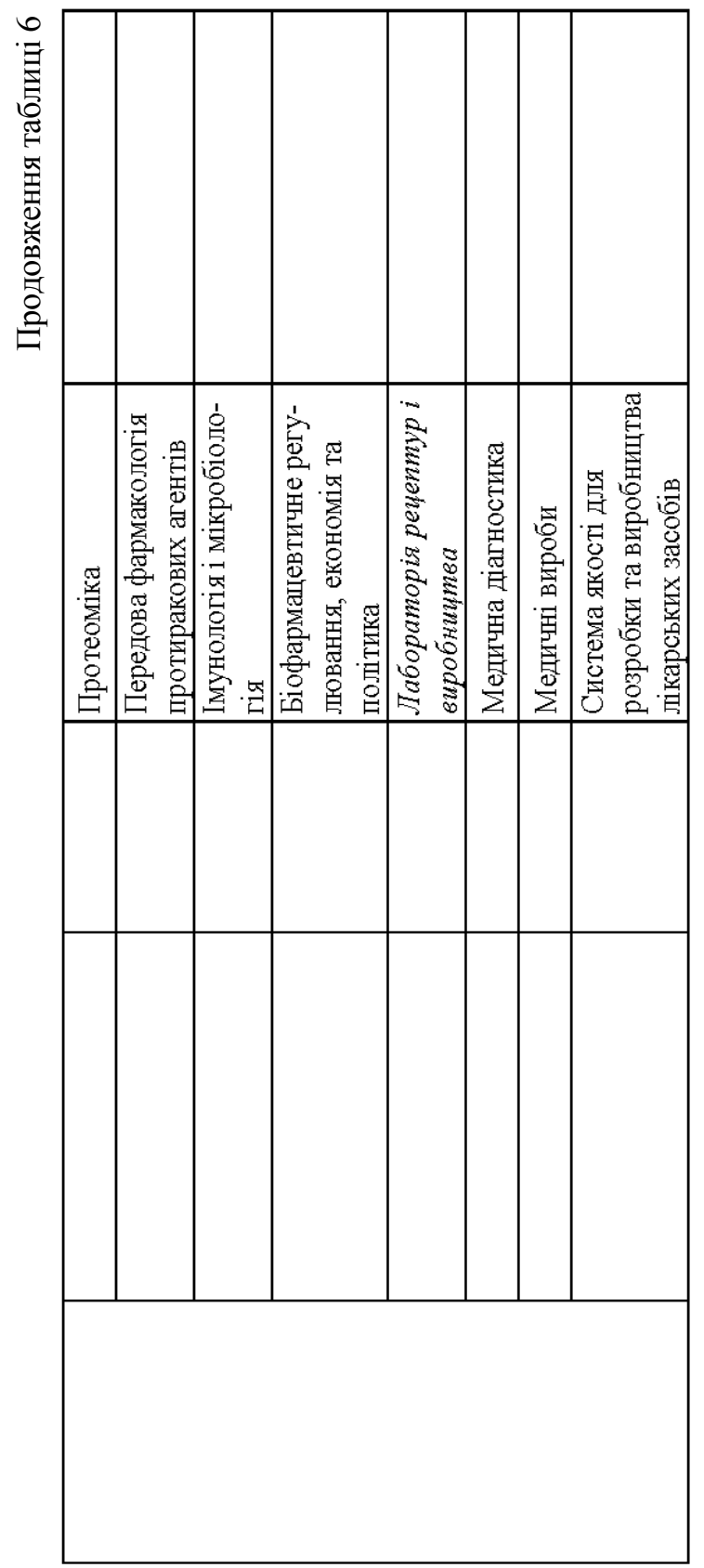
Інформаційний сайт Бруклінського фармацевтичного коледжу Університету Лонг-Айленду (США) (2019р.) містить окремі посилання: про коледж та фармацію; про навчання студентів; про сучасні методи навчання; про факультети та програми навчання. Вимоги для вступників (2019 р.) передбачають дві програми навчання: 12 кред., якщо є рівень магістра фармації та 39 кред., якщо немає рівня навчання магістр фармації. Вказано назви дисциплін та кредити, які відведено для їх вивчення. Вказана електронна адреса для подання інформації, контактний телефон. Інформаційний сайт Іллінойського університету (Чикаго, США) (2020 р.) містить адресу, контактну інформацію, коди програм, вимоги для поступлення. Програма представлена у вигляді переліку навчальних тем та розподілу годин, відведених на кожну тему.

На третьому рівні підготовки спеціалістів для фармацевтичної галузі як в Україні, так і за кордоном всі ОНП ЗВО мають суттєві відмінності, позаяк кожний навчальний заклад пропонує певну направленість наукового пошуку, яка притаманна ЗВО та вмотивована насамперед наявністю творчого наукового складу майбутніх керівників дисертаційних робіт. Також, на нашу думку, це явище можна обгрунтувати тим, що й сама фармацевтична галузь має багатовекторні як наукові, так і практичні аспекти діяльності. Науковий пошук може провадитись щодо хімічного синтезу як нових оригінальних, так і генеричних діючих речовин (активних фармацевтичних інгредієнтів) (АФІ) та допоміжних речовин; створенню на основі отриманих АФІ лікарських форм та впровадження їх у виробництво; контролю якості АФІ та готових лікарських форм на їх основі; досліджень управління системами забезпечення якості Л3; досліджень роздрібного та гуртового обігу Л3; менеджменту та маркетингу; виготовленню ЛЗ в умовах аптечного закладу та багатьом іншим напрямам.

За складниками ОНП майбутній аспірант повинен зрозуміти та співставити сферу інтересів та можливостей $3 \mathrm{BO}$ та своїх власних наукових інтересів.

\section{ВИСНОВКИ}

Забезпечення якості вищої освіти за спеціальністю 226 «Фармація, промислова фармація» в Україні потребує гармонізації освітніх програм для всіх рівнів навчання 3 програмами ЗВО у СС та провідних країнах світу. 
Акредитація освітніх програм відбувається за участі НАЗЯВО, яке спонукає $3 \mathrm{BO}$ в Україні до самоаналізу та проведення порівняльного аналізу освітньо-навчальних програм (ОПП та ОНП) 3 навчальними закладами, які випускають кваліфікованих фахівців у відповідній галузі, як в Україні, так і в світі.

Проведено порівняльний аналіз ОПП та ОНП другого (магістерського) та третього (аспірантського) рівнів освіти зі спеціальності 226 «Фармація, промислова фармація», в результаті якого виявлено спільні та відмінні характеристики навчального навантаження за групами компонентів та циклами підготовки університетів Свропи та світу.

Проаналізовані нами освітні програми для другого рівня вищої освіти мали відповідну загальну кількість кредитів, зокрема для ОПП магістерського рівня - 90 кредитів, для ОНП магістерського рівня - 120 кредитів. Однак кожна 3 цих програм має свої особливості та переваги, оскільки вектор програми спрямований відповідно до освітньо-наукових аспектів ЗВО. Наприклад, в ОНП The Uppsala University (Sweden) значна частина кредитів відводиться на дисципліни, що стосуються статистичних методів, комп'ютерних технологій, математичного моделювання, молекулярного моделювання під час розробки лікарських засобів.

Аналіз ОНП третього освітньо-наукового рівня дозволив встановити значну відмінність програм як за кредитами, так і за спрямованістю освітньо-наукових інтересів, які визначаються широтою потреб фармацевтичної галузі.

Проведений аналіз також свідчить про те, що для першого ознайомлення на офіційному сайті ЗВО, на нашу думку, доцільніше подавати стислу інформацію про ОНП, а також представляти контактні дані відділів аспірантури чи гарантів ОНП. Слід зауважити, що саму ОНП краще представляти окремим блоком для детального ознайомлення майбутнього аспіранта.

\section{АНОТАЦІЯ}

Геополітичні, економічні та соціально-культурні зміни, які відбуваються в Україні, певним чином впливають на наукову спільноту та освітньо-навчальний процес у ЗВО. Необхідність імплементування законодавчих та нормативно-правових актів, які регламентують функціонування фармацевтичної галузі України, до законодавчої бази ЄС відобразилась та внесла суттєві зміни 
в структуру та підходи до навчання у ЗВО. У монографії проаналізовано причини та підгрунтя процесу акредитації в Україні, який спонукав як до оновлення освітньо-наукових та освітньонавчальних програм, так і до змін щодо самого процесу навчання на другому та третьому рівнях вищої освіти у ЗВО за спеціальністю 226 «Фармація, промислова фармація». Порівняльний аналіз ОНП і ОПП другого (магістерського) рівня навчання за вказаною спеціальністю дозволив встановити незначні відмінності ОНП в ЗВО України навіть за умови відсутності стандарту. Також було опрацьовано закордонні ОНП та встановлена можливість їх порівняння 3 ОНП Національного університету «Львівська політехніка» як за освітніми складниками, так і за кількістю кредитів. Порівняльний аналіз ОНП третього рівня навчання довів доволі суттєві відмінності як між вітчизняними, так і закордонними ОНП ЗВО. Опрацьовано підхід для подачі на інформаційних сайтах ЗВО необхідного обсягу щодо ОНП для можливості віддаленого пошуку майбутнім аспірантом спорідненості власних наукових інтересів та можливостей ЗВО щодо забезпечення виконання майбутньої кандидатської роботи.

\section{ЛІТЕРАТУРА}

1. Мельничук О.Ф. Правові засади діяльності Національного агентства із забезпечення якості вищої освіти в умовах євроінтеграції. Публічне право: науково-практичний юридичний журнал. 2017. № 1 (25). С. 67-72.

2. Солоденко А.К., Погребняк В.П., Дашковська О.В. Національне агентство із забезпечення якості вищої освіти - довгий шлях створення. Вісник Національного технічного університету «ХПI» : зб. наук. пр. Харків : НТУ «ХПІ». 2019. № 9 (1334). С. 4-8. (doi: 10.20998/2079-8024.2019.9.01).

3. Про утворення Національного агентства із забезпечення якості вищої освіти. Постанова КМУ № 244 від15.04.2015, поточна редакція від 28.08.2019. URL: https://zakon.rada.gov.ua/laws/show/ 244-2015-п.

4. Серняк O.I. Незалежний освітній аудитор як суб'єкт громадського механізму забезпечення якості вищої освіти. Демократичне врядування: наук. вісн. Вип. 1(23) / за ред. чл.-кор. НАН України В.С. Загорського, доц. А.В. Ліпенцева. Львів : ЛРІДУ 
НАДУ，2019. URL: www.dv.lvivacademy.com (doi:https://doi.org/ 10.33990/2070-4038.23.2019.181484).

\section{Information about the authors:} Krychkovska A. M.,

Candidate of Pharmaceutical Sciences, Associate Professor, Associate Professor at the Department of Technology of Biologically Active Substances, Pharmacy and Biotechnology Lviv Polytechnic National University 12, Stepana Bandery str., Lviv, 79000, Ukraine

Zayarnyk N. L.,

Candidate of Pharmaceutical Sciences, Associate Professor, Associate Professor at the Department of Technology of Biologically Active Substances, Pharmacy and Biotechnology Lviv Polytechnic National University 12, Stepana Bandery str., Lviv, 79000, Ukraine

Konechna R. T.,

Candidate of Pharmaceutical Sciences, Associate Professor at the Department of Technology of Biologically Active Substances, Pharmacy and Biotechnology Lviv Polytechnic National University 12, Stepana Bandery str., Lviv, 79000, Ukraine 